Article

\title{
Emergy and Economic Evaluation of Seven Typical Agroforestry Planting Patterns in the Karst Region of Southwest China
}

\author{
Zhigang Zou ${ }^{1,2,3}$, Fuping Zeng ${ }^{1,3}$, Kelin Wang 1,3, Zhaoxia Zeng 1,3, Leilei Zhao ${ }^{4}$, Hu Du 1,3, \\ Fang Zhang ${ }^{1,2,3}$ and Hao Zhang ${ }^{1,3,5, *}$
}

1 Key Laboratory of Agro-Ecological Processes in Subtropical Region, Institute of Subtropical Agriculture, Chinese Academy of Sciences, Changsha 410125, China; zhigangzou0203@163.com (Z.Z.); fpzeng@isa.ac.cn (F.Z.); kelin@isa.ac.cn (K.W.); elizeberth@163.com (Z.Z.); hudu@isa.ac.cn (H.D.); zhangf@isa.ac.cn (F.Z.)

2 University of Chinese Academy of Sciences, Beijing 100049, China

3 Huanjiang Observation and Research Station for Karst Ecosystem, Chinese Academy of Sciences, Huanjiang 547100, China

4 China Forest Exploration \& Design Institute in Kunming, Kunming 650216, China; zhaollsd@163.com

5 College of Agricultural Sciences and Natural Resources, University of Nebraska-Lincoln, Lincoln, NE 68583, USA

* Correspondence: zhanghao@isa.ac.cn; Tel.: +186-8467-6587

Received: 18 January 2019; Accepted: 6 February 2019; Published: 7 February 2018

\begin{abstract}
As a vast degraded land ecosystem, the karst region of southwest China is currently experiencing serious conflicts between restoration of degraded vegetation communities and agricultural activities. Furthermore, it is not clear what land use pattern suits local farmers best. To evaluate the sustainability of the degraded agricultural ecosystems in the region, methods for emergy analysis were used to compare the ecological and economic benefits from seven typical agroforestry planting patterns in the Yunnan province. The eco-efficiencies of the apple pattern $(\mathrm{AP})$, pear pattern (PP), pomegranate pattern (PRP) were all lower than that of the traditional corn pattern $(\mathrm{CP})$, although the economic benefit was higher than that of $\mathrm{CP}$. Ecological benefits of the apple-soybean pattern (ASP) and the pear-pumpkin pattern (PPP) were not significantly improved, while ecological and economic benefits of the pomegranate-grass-sheep pattern (PGSP) was improved significantly. Intercropping pumpkin in PP increased the economic efficiency by $28.3 \%$, which was superior to that of the intercropping of soybeans $(4.6 \%)$ in AP. These data implied that interplanting crops in AP and PP might result in higher economic benefit than the existing interplanting pattern. The multistory agroforestry planting pattern and raising in PGSP could optimize the relationship among tree-grass-sheep and improve ecological and economic benefits. Additionally, scenario analysis showed that local farmers might enjoy better ecological and economic benefits at a large scale by optimizing current agricultural production patterns. Our results suggest that together, both the local government and farmers can adjust the structure of agroforestry ecosystems to foster the sustainable development of the ecological industry in the karst region of China.
\end{abstract}

Keywords: emergy analysis; agroforestry; fruit tree; degraded ecosystem; sustainable development

\section{Introduction}

Desertification is a global natural or unnatural phenomenon involving the progressive decline or loss of land productivity due to the lack of rain, vegetation destruction, wind erosion, water erosion, soil salinization [1]. As one of the most remarkable cases of desertification, rocky desertification is 
common in karst regions, which cover an area of some 22 million $\mathrm{km}^{2}$ that account for approximately $15 \%$ of the total land area worldwide [2]. Eroded land ecosystems in rocky desertification regions are suffering from many ecological problems, serious soil erosion, mainly, a sharp decline in forest area, rapid reduction of biodiversity and habitat poor economic development [3]. In China, the rocky desertification area comprised some $129,000 \mathrm{~km}^{2}$ in 2015, including Hunan, Hubei, Guangdong, Guangxi, Guizhou, Yunnan, Chongqing and Sichuan provinces [4]. The low disaster-tolerance and environmental capacities of these areas has largely limited land use and economic development of the local population, which poses a direct threat to the ecological security of the Yangtze and Zhujiang river basins in China [5].

To reduce the rate of land degradation and to promote ecological and economic development, the government of the People's Republic of China started the nationwide comprehensive management of rocky desertification in 2008 and the Grain for Green Program (GGP) to convert cropland to grassland and forest, in 1999 [6]. Until 2017, a total area of 66,000 km² in 451 rocky desertification counties has been subjected to vegetation restoration work, fruit tree planting, forage cultivation, cattle raising, among others [7]. Many researches on rocky desertification management have evaluated a series of agroforestry ecological restoration and ecological development patterns as well, comprehensive management of agricultural and forestry systems, construction of small water-conservation projects, conversion of farmland to forest and grassland, new cooperative organizations in rural regions $[8,9]$. For example, Huajiang pattern emphasizes the Chinese prickly ash, dragon fruit plantation, leguminous forage grown under the plantation trees, raising livestock and poultry, development of rural biogas from animal droppings, reuse of waste residue in the biogas digester [10,11]. In order to compare the economic benefits and ecological benefits of these ecological patterns, many studies have adopted different methods for comprehensive evaluation [12-14]. However, due to the differences in evaluation methods and indicators, it is difficult to provide quantitative and unified conclusions to support the decisions of farmers or policy makers [15,16]. Therefore, it is necessary to evaluate different patterns of rock desertification by means of a unified objective quantification scheme.

Emergy analysis theory, which can convert all kinds of different categories of energy and matter to the same standard values, was first proposed for quantitative analysis in the 1990s [17]. This theory was widely used to solve the energy unit-inconformity in different nature or social systems; to measure the real value of the natural environment resources and economic activities; to analyze the relationship among components of a complex system, to harmonize ecological protection and economic and social development [18-21]. In recent decades, there have been many applications of this theory on the input-output analysis of agricultural ecosystems [22,23] to assess the level of social sustainable development [24], dynamic analysis [25,26], scenario forecasting [27]. However, most of these researches focused on the assessment of agricultural systems and farming-stockbreeding biogas systems in non-karst areas.

The karst region of southwest China is the largest land degraded ecosystem testifying to the increasingly serious conflicts between degraded vegetation restoration efforts and activities related to agricultural production [28-30]. Yunnan Province is located in the western part of this region and shows the most acute rocky desertification process in it. As is the case in the Guizhou and Guangxi provinces, the local government and people of Yunnan province have also implemented some well-known agroforestry planting ecosystems to control rocky desertification [31,32]. However, it is still unclear what pattern is best suited for the local people. In the present study, emergy and economic methods were used to evaluate these agroforestry planting patterns. Our objectives were the following: 1) to assess the emergy value of typical agroforestry planting patterns, 2) to optimize these patterns by adding ecological subsystem, and, 3) to provide the technical support for land use sustainability to the local government and farmers. 


\section{Materials and Methods}

\subsection{Research Area}

The seven agroforestry planting patterns were located at Mengzi City, Honghe Hani \& Yi Autonomous Prefecture, Yunnan Province, China $\left(23^{\circ} 23^{\prime} 55^{\prime \prime} \mathrm{N}, 103^{\circ} 23^{\prime} 43^{\prime \prime} \mathrm{E}\right)$. The research area belongs to the typical karst area of faulted basins that has suffered from very serious rocky desertification. The highest and lowest elevations are $2567.8 \mathrm{~m}$ and $146 \mathrm{~m}$, respectively. The climate belongs to the subtropical plateau monsoon climate with average annual temperature of $18.6^{\circ} \mathrm{C}$. The average annual rainfall is $815.8 \mathrm{~mm}$. The annual frost-free period is 337 day, the average number of annual sunshine hours is $2234 \mathrm{~h}$. Based on the statistical yearbook, government report data, our field survey data, we studied the variation of emergy values in the following agroforestry planting patterns: corn planting $(\mathrm{CP})$, apple planting $(\mathrm{AP})$, apple-soybean inter-planting (ASP), pear planting (PP), pear-pumpkin inter-planting (PPP), pomegranate cultivation (PRP), pomegranate-grass-sheep (PGSP) (Table 1).

Table 1. Background information for the seven agroforestry planting patterns.

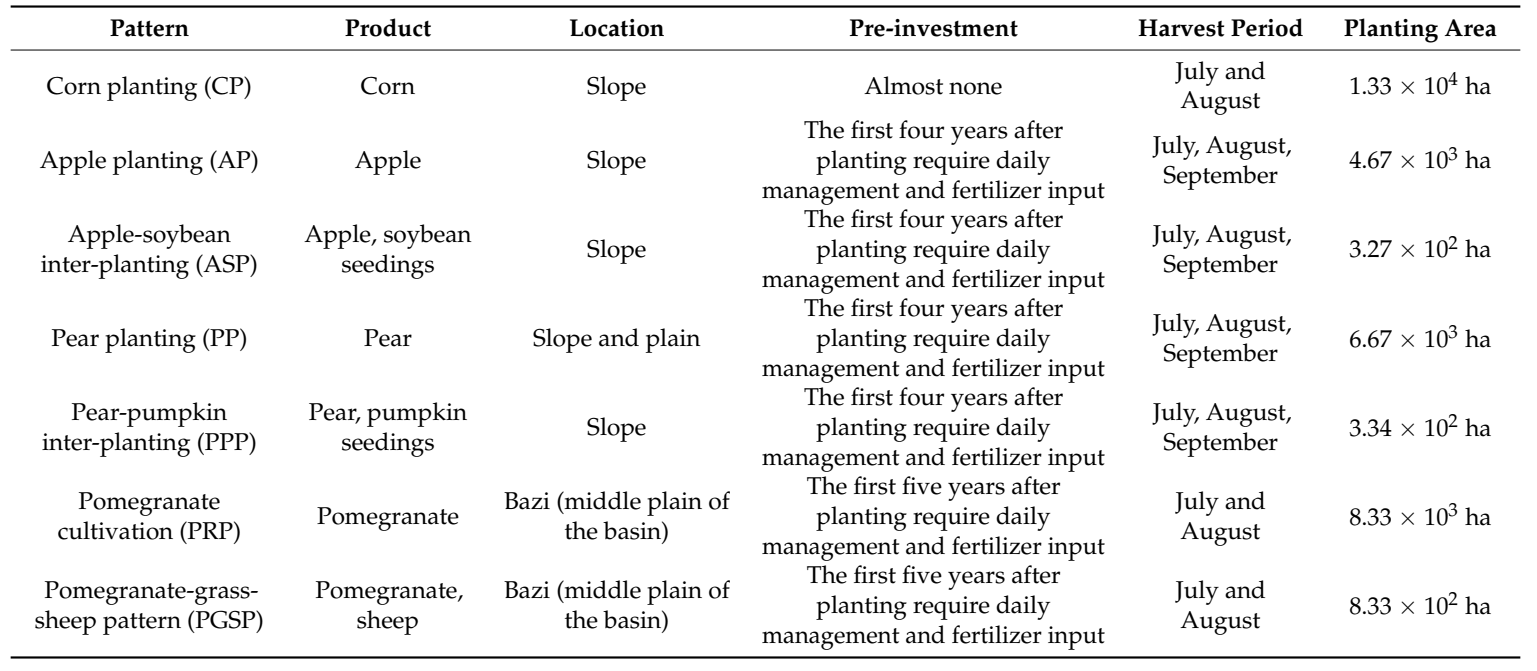

\subsection{Description of the Seven Agroforestry Planting Patterns}

\subsubsection{Corn Planting (CP) Pattern}

The Yunnan Statistical Yearbook in 2016 showed that the corn planting area is approximately $1,517,000$ ha, which accounts for $21 \%$ of the total grain crop acreage in the province. Farmers plant corn on the karst soil directly and harvest it from July to August each year. This pattern is a basic planting pattern among agroforestry planting patterns.

\subsubsection{Apple Planting (AP) Pattern}

Apple trees are planted mainly in Xibeile Town, Xin'ansuo Town, Laozhai Miao Township of Mengzi City. Total planting area has reached 6000 ha. Due to the government policy for its promotion, the apple planting area in Mengzi City is gradually expanding. Because of its prevailing special conditions, such as high altitude, low latitude, large temperature difference between day and night, sugar content in apples in Mengzi city may be as high as $17 \%-20 \%$, making them some of the sweetest apples in Southwest, China. Four years after planting, apple trees begin to enter the fruiting period in the 5th year. Some early maturing apple varieties begin ripening in early July, while late maturing varieties begin to ripen in early September. 


\subsubsection{Apple-Soybean Inter-Planting (ASP) Pattern}

Farmers have planted apples for more than 30 years in Mengzi City. Some farmers spontaneously plant soybeans under apple trees for extra income. Interplanting soybeans can increase economic output, while soybean roots and leaves increase soil organic matter. Intercropping also helps to reduce orchard soil erosion. Soybeans are usually sown from mid-April to May and the harvesting period comes at the end of August. Different demands in labor-intensive periods provide for full use of farmers labor.

\subsubsection{Pear Planting (PP) Pattern}

The history of pear-tree planting in Mengzi City is as long as that of apple-tree planting. The area occupied by pear-tree orchards in 2017 was about 3000 ha in Mengzi city, which is half of apple-tree orchards. According to the overall planning by the local government, the Plateau pear industry is mainly distributed in Luxi County, whose area will be more than 10,000 ha by the year 2020 . The growth period of Plateau pears is about 45 days, which is shorter than that of Northern varieties, thus, has a potential advantage in the fruit market. Five years after planting, pear trees will enter the fruiting period and Plateau pears are harvested from July to August every year.

\subsubsection{Pear-Pumpkin Inter-Planting (PPP) Pattern}

Some farmers cultivate pumpkins under pear trees to increase land use efficiency and economic benefit. Pumpkin seeds are usually sown at the beginning of April and harvest takes place from August to September.

\subsubsection{Pomegranate Cultivation (PRP) Pattern}

The history of pomegranate plantation in Mengzi City dates back over 800 years. In 2017, the total area of pomegranate plantations was about $8000 \mathrm{ha}$, accounting for $48 \%$ of the orchard area in Mengzi city. It has obtained many awards by local government for its good land use efficiency and industrial development for local farmers. In recent years, sweet-seeds pomegranate with good fruit appearance and early maturity has dominated the local market. The pomegranate tree begins fruiting 10 years after planting, fruit harvest takes place in July-August.

\subsubsection{Pomegranate-Grass-Sheep Pattern (PGSP)}

To increase economic output and reduce overall economic investment, local farmers have developed an ecological engineering pattern of pomegranate-grass-livestock based on a single planted pomegranate. In this pattern, the proper amount of pasture was planted under each pomegranate tree, a certain number of stabled sheep are fed grass. Pasture can make full use of the space under the pomegranate trees, the manure produced by the sheep can be directly used as a fertilizer for pomegranates and pasture.

\subsection{Data Collection and Sample Analysis}

In this study, the questionnaire survey data, field sample data and government statistics data were mainly used. To collect basic economic data and agricultural performance of various patterns, five semi-structured questionnaire surveys on farmers, cooperatives, fertilizers, seeds, pesticide sellers for each pattern were conducted in 2017 . At the same time, the soil $(0-100 \mathrm{~cm})$ and plant samples of the corresponding farmers were collected during the questionnaire survey to determine soil bulk density, water content, total nitrogen, total phosphorus, total potassium, organic carbon content. Soil bulk density was measured by the ring knife method and soil water content was determined by the drying method. Total nitrogen and total phosphorus were digested with $\mathrm{H}_{2} \mathrm{SO}_{4}$ and measured by indophenol blue colorimetry and Mo-Sb colorimetry, respectively. Total potassium was measured by ICP emission spectrometry determination and total organic carbon content was measured by the 
$\mathrm{K}_{2} \mathrm{Cr}_{2} \mathrm{O}_{7}$ method [33]. In addition, the raw data on renewable natural inputs, which include incoming solar radiation, precipitation, wind speed were obtained from the weather station located at the agricultural research site. Regional agricultural acreage and development planning data were collected from the government statistics (2010-2017).

All the pre-constructions of the patterns have been completed before the research. The pre-investment per year is calculated as the ratio of pre-investment and payback period, has been considered in the economic and emergy evaluation.

\subsection{Data Analysis}

\subsubsection{Emergy Analysis}

There are three steps for emergy analysis in agroforestry planting pattern, namely drawing an aggregated system diagram, establishing emergy tables, construction of emergy-based indices. After investigating the whole system, an aggregated system diagram was drawn in accordance with the energy circuit symbols proposed by Odum in 1983 [34], which illustrates the boundaries of the system, the major components and their interactions, the materials, money and energy flows (Figure 1). On the basis of the system diagram, the emergy table is used to classify the different input and output flows, to convert the traditional units (J; g; yuan; etc.) into the unified unit (sej). Inputs are categorized as natural resources (I), purchased resources $(\mathrm{F})$, system outputs $(\mathrm{U})$. $\mathrm{U}$ is equal to the sum of yield $\left(\mathrm{Y}_{1}\right)$ and ecological benefits $\left(\mathrm{Y}_{2}\right)$. F were separated into the renewable purchased resources $\left(\mathrm{F}_{\mathrm{R}}\right)$ and the non-renewable purchased resources $\left(\mathrm{F}_{\mathrm{N}}\right)$. Natural resources (I) was consisted of renewable natural resources $(R)$ and non-renewable natural resources $(N)$. Renewable natural resources include sunlight and wind. An example of a nonrenewable natural resource is top soil loss and purchased resources include labor, fertilizer, irrigation water and seed. Emergy values are based on the benchmark calculation of $12.0 \mathrm{E}+24 \mathrm{sej} \mathrm{a}^{-1}$. The emergy values of all products and services were calculated using the following formula:

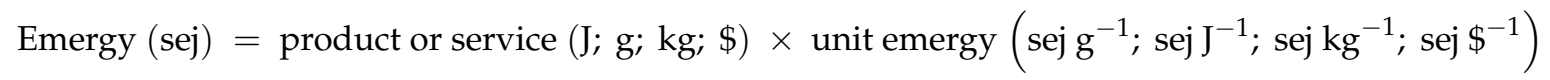

All data were converted to values per ha per year. $90 \%$ of the required energy input of the required labor force is treated as non-renewable purchased resources $\left(\mathrm{F}_{\mathrm{N}}\right)$ in this study, the remaining $10 \%$ is classified as renewable purchased resources $\left(\mathrm{F}_{\mathrm{R}}\right)$ [20].

The final step is calculation of emergy-based indices used to assess various aspects of performance, such as resource use efficiency, environmental impact, system sustainability. Just as other studies on the sustainability of agricultural systems [35-37], emergy-power density (EPD), emergy self-sufficiency ratio (ESR), emergy yield ratio (EYR), environmental loading ratio (ELR), emergy restoration ratio (ERR), emergy benefit ratio (EBR) and emergy sustainability index (ESI) were used for balanced emergy analysis (Table 2, Table A1). 
Table 2. Emergy evaluation indices in this research.

\begin{tabular}{|c|c|c|}
\hline Index & Function & Definition \\
\hline Emergy-power density (EPD) & $\mathrm{U} /$ area & $\begin{array}{c}\text { Intensity and level of economic } \\
\text { development }\end{array}$ \\
\hline Emergy self-sufficiency ratio (ESR) & $\mathrm{I} / \mathrm{U}$ & $\begin{array}{l}\text { Degree of self-sufficiency and } \\
\text { dependence on the outside world. } \\
\text { The autarkic ability of the system } \\
\text { is direct proportion to the ESR. }\end{array}$ \\
\hline Emergy yield ratio (EYR) & $\mathrm{Y}_{1} / \mathrm{F}$ & $\begin{array}{l}\text { Net contribution to the economy } \\
\text { beyond its own operation }\end{array}$ \\
\hline Environmental loading ratio (ELR) & $\left(\mathrm{N}+\mathrm{F}_{\mathrm{N}}\right) /\left(\mathrm{R}+\mathrm{F}_{\mathrm{R}}\right)$ & $\begin{array}{l}\text { Reflects system environmental } \\
\text { stress and sustainability }\end{array}$ \\
\hline Emergy restoration ratio (ERR) & $\mathrm{Y}_{2} / \mathrm{F}$ & $\begin{array}{l}\text { Ecological benefits of } \\
\text { rocky-desertification control }\end{array}$ \\
\hline Emergy benefit ratio (EBR) & $\left(Y_{1}+Y_{2}\right) / F$ & $\begin{array}{l}\text { Ecological and economic benefits } \\
\text { of rocky-desertification control }\end{array}$ \\
\hline Emergy sustainability index (ESI) & EYR/ELR & $\begin{array}{l}\text { Sustainability of the system. ESI } \\
\text { value ranged from } 1 \text { to } 10 \text {, is direct } \\
\text { proportion to the sustainability of } \\
\text { the production system. }\end{array}$ \\
\hline
\end{tabular}

Note: I: Natural Resources. R: Renewable natural resources. N: Non-renewable natural resources. F: Purchased resources. $F_{R}$ : Renewable purchased resources. $F_{N}$ : Non-renewable purchased resources. $U=I+F$. $Y_{1}=U$, system outputs. $\mathrm{Y}_{2}$, ecological benefits for water conservation (WC), soil reinforcements (SR) and fertility (FE), carbon fixation $(\mathrm{CF})$, oxygen production $(\mathrm{OP}), \mathrm{Y}_{2}=\mathrm{WC}+\mathrm{SR}+\mathrm{FE}+\mathrm{CF}+\mathrm{OP}$.

\subsubsection{Economic Analysis}

The economic output/input ratio, unit economic benefit (UEB), unit net economic benefit (UNEB) were used for economic analysis (TableA2). Economic output/input ratios can be used for measurement of economic cost efficiency, while UEB and UNEB are used for the measurement of the economic benefits from the whole agriculture ecosystem.

$$
\begin{gathered}
\mathrm{UEB}=\mathrm{O}-\mathrm{I}, \\
\mathrm{UNEB}=\mathrm{O}-\mathrm{I}_{a}, \\
\mathrm{I}=\mathrm{I}_{a}+\mathrm{I}_{f},
\end{gathered}
$$

O: System economic output. I: System economic input. $\mathrm{I}_{a}$ : the actual economic input of the system, $I_{f}$ : the free input of the system, which is equal to the market value of the labor and manure input of farmers themselves.

\subsubsection{Scenario Analysis}

Scenario analysis is a quantitative and qualitative combination method [38] used to compare and study the possible status under different trend conditions. Scenario analysis can predict the long-term outcome of studies with clear-cut factors and is well suited to predicting the status of policy or to measure implementation years later [39]. In this research, we constructed a baseline scenario (BS), an improvement scenario (IS), an optimization scenario (OS) based on field research data, expert experience and relevant plans of the Mengzi Municipal Government (Table 3). The ratio of area conversion in the optimization scenario was calculated by the maximum value in the implemented plan. All ratios of these conversion were optimized by the recommendations of experts. 
Table 3. Setting and comparing of different scenarios.

\begin{tabular}{|c|c|c|}
\hline Scenarios & Definition & Status after 5 years \\
\hline $\begin{array}{l}\text { Baseline } \\
\text { scenario }\end{array}$ & $\begin{array}{l}\text { Government and business have not adjusted the } \\
\text { existing promotion and subsidy policies; } \\
\text { the regional planting structure has not changed } \\
\text { significantly. There is no major technological } \\
\text { change in farming methods. }\end{array}$ & $\begin{array}{l}\text { Pomegranate planting area is } 10,000 \mathrm{ha}, 10 \% \text { of } \\
\text { which is PGSP. Apple planting area is } 6330 \mathrm{ha} \text {, } \\
7 \% \text { of which is ASP. Pear planting area is } 3000 \mathrm{ha} \text {, } \\
5 \% \text { of which is PPP. Corn planting area is } 13,670 \text { ha. }\end{array}$ \\
\hline $\begin{array}{l}\text { Improvement } \\
\text { scenario }\end{array}$ & $\begin{array}{l}\text { Government and business have promoted the } \\
\text { transformation of the planting structure, } \\
\text { especially the transition from original planting } \\
\text { patterns to ecological planting patterns. }\end{array}$ & $\begin{array}{l}\text { Pomegranate planting area is } 10,600 \mathrm{ha}, 15 \% \text { of } \\
\text { which is PGSP. Apple planting area is } 7000 \mathrm{ha} \text {, } \\
10 \% \text { of which is ASP. Pear planting area is } 3000 \mathrm{ha} \text {, } \\
7 \% \text { of which is PPP. Corn planting area is } 12,400 \text { ha. }\end{array}$ \\
\hline $\begin{array}{l}\text { Optimization } \\
\text { scenario }\end{array}$ & $\begin{array}{l}\text { Based on the improvement scenario, the } \\
\text { government has promoted the transformation of } \\
\text { corn cultivation to pomegranate and apple, } \\
\text { actively promoted the transformation of the } \\
\text { traditional patterns to the ecological patterns. }\end{array}$ & $\begin{array}{c}\text { Pomegranate planting area is } 11,330 \mathrm{ha}, 30 \% \text { of } \\
\text { which is PGSP. Apple planting area is } 8670 \mathrm{ha} \text {, } \\
15 \% \text { of which is ASP. Pear planting area is } 3000 \mathrm{ha} \text {, } \\
10 \% \text { of which is PPP. Corn planting area is } 10,000 \\
\text { ha. }\end{array}$ \\
\hline
\end{tabular}

\section{Results}

\subsection{Emergy Analysis of Seven Typical Agroforestry Planting Patterns}

The traditional CP has the simplest structure of emergy systems in these patterns (Figure 1). With the addition of subsystems, the emergy system structure of PGSP became more complex than before. Except for CP and PGSP, the other five emergy systems showed similar structure. The proportions of seed, sheep, fertilizer and pesticide in all planting patterns were very large. The manure and compound fertilizer in CP accounted for $45.5 \%$ and $32.7 \%$ of total investment, respectively, which accounted for $78.2 \%$ of the grand total (Figure 2). The fertilizer input in the PRP also accounts for an absolute dominant position. In addition, over $60 \%$ of fertilizer consumption in PP, PPP, AP, ASP is mainly as compound fertilizers; $94.6 \%$ of fertilizer consumption in PRP pattern is in the form of organic fertilizer. When grass is added to the sheep subsystem, the proportion of fertilizer dropped to $30.7 \%$ and the input ratio of seeds and mutton increased from $0.66 \%$ to $64.5 \%$. Thus, total emergy input in PRP was $2.67 \times \mathrm{E}+17 \mathrm{sej}^{-1} \cdot \mathrm{ha}^{-1} \cdot \mathrm{year}^{-1}$, while that in CP was $1.69 \times \mathrm{E}+16 \mathrm{sej}^{-1} \cdot \mathrm{ha}^{-1} \cdot \mathrm{year}^{-1}$. Subsystem addition to PRP reduced total input of emergy by $19.6 \%$, which indicated that the addition of subsystem significantly reduces the input requirements for external emergy in PRP. The emergy input in AP $\left(2.16 \times \mathrm{E}+16 \mathrm{sej} \cdot \mathrm{hm}^{-1} \cdot \mathrm{a}^{-1}\right)$ was slightly higher than that of PP $\left(1.83 \times E+16 \mathrm{sej} \cdot \mathrm{hm}^{-1} \cdot \mathrm{a}^{-1}\right)$. Similarly, it was different in the impact of the interplanting and grass-sheep subsystem on PP. PPP and ASP increased the demand for external emergy by $6.6 \%$ and $4.0 \%$, respectively. 

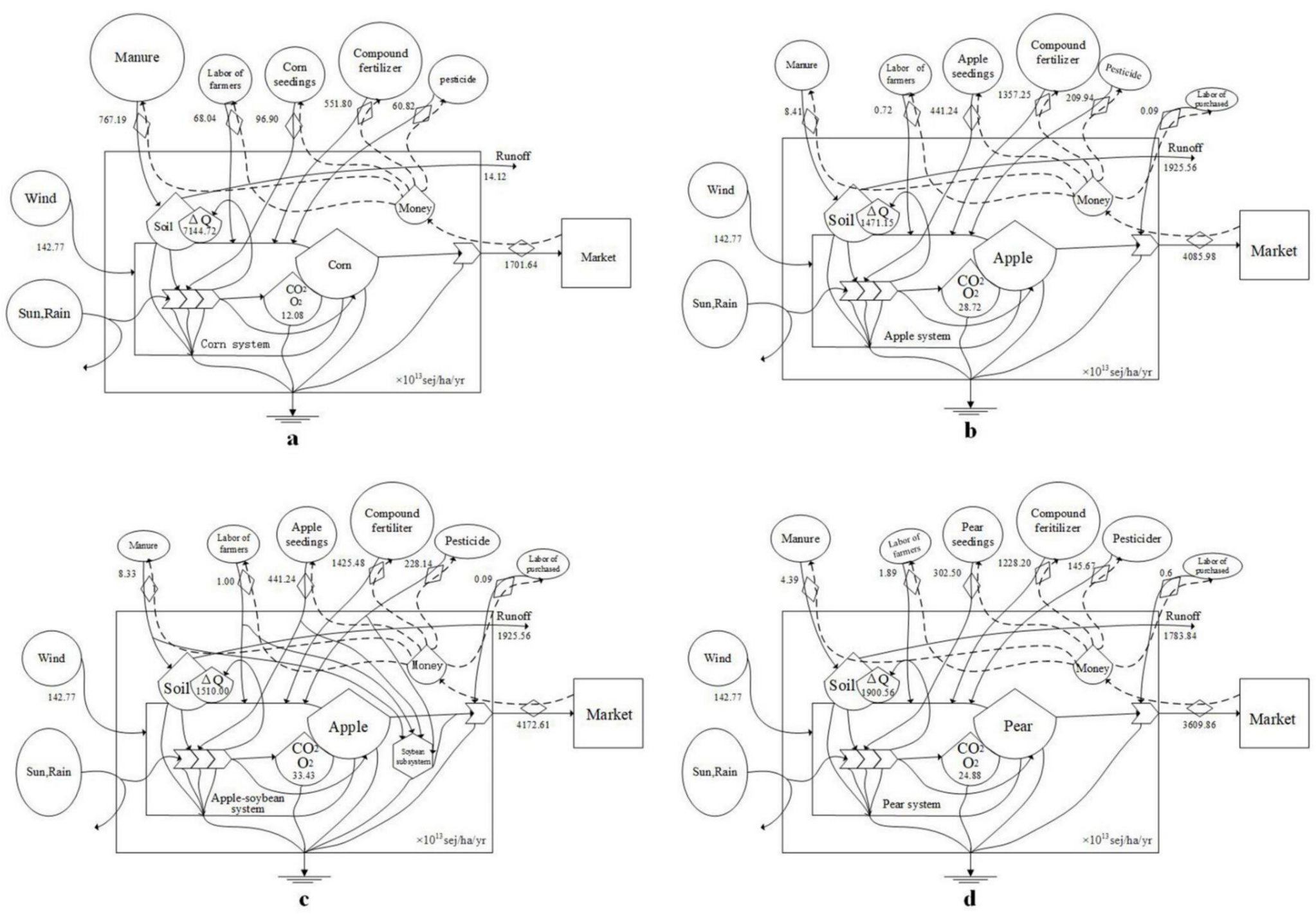

Figure 1. Cont. 

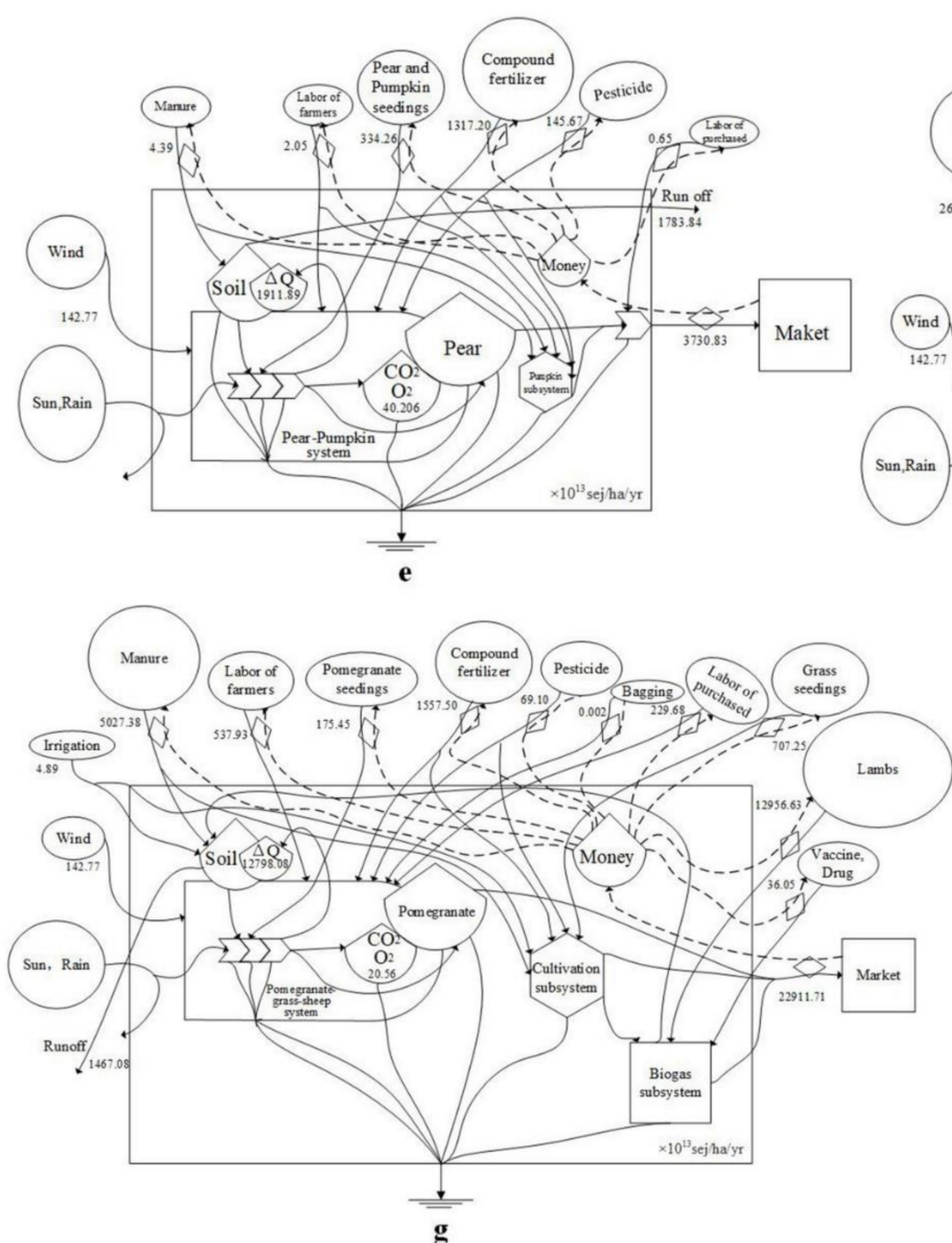
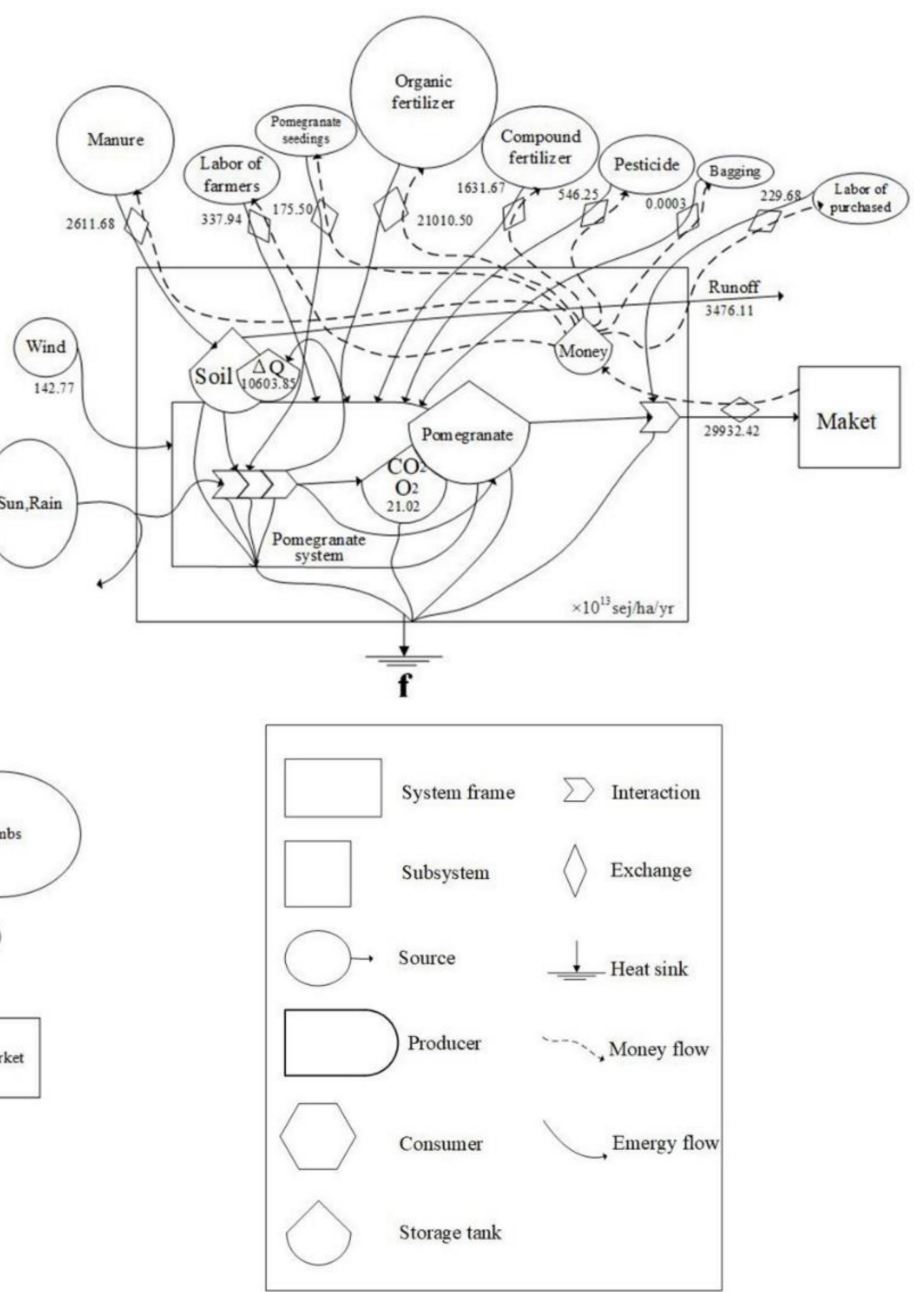

Figure 1. The emergy systems of seven typical agroforestry planting. a: Corn planting (CP) pattern. b: Apple planting (AP) pattern. c: Apple-soybean inter-planting (ASP) pattern. d: Pear planting (PP) pattern. e: Pear-pumpkin inter-planting (PPP) pattern. f: Pomegranate cultivation (PRP) pattern. g: Pomegranate-grass-sheep pattern (PGSP). 


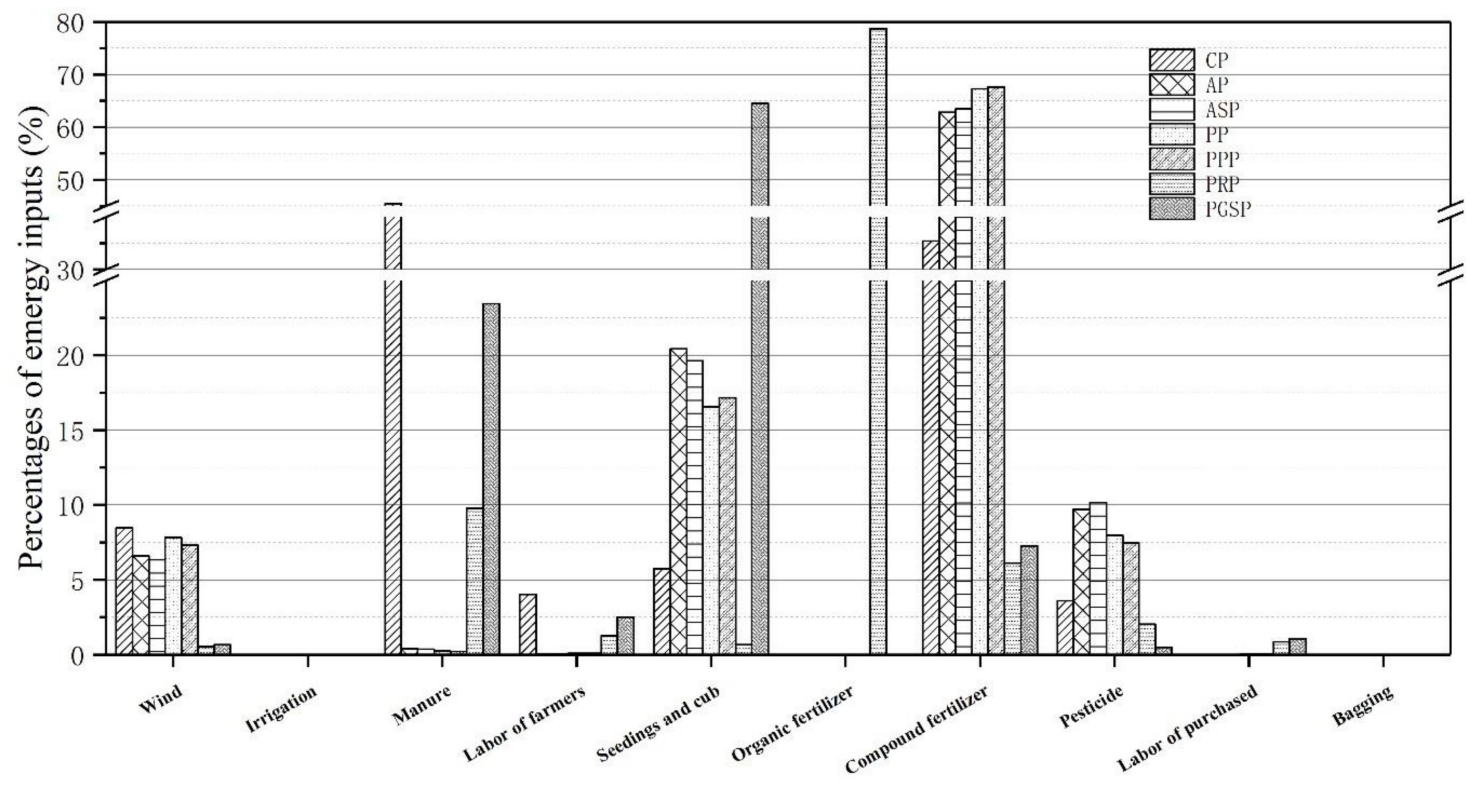

Figure 2. Emergy inputs percentages of the seven typical agroforestry planting patterns.

CP showed the lowest emergy-power density (EPD) $\left(18.20 \times \mathrm{E}+11 \mathrm{sej}^{-1} \cdot \mathrm{ha}^{-1} \cdot \mathrm{year}^{-1}\right)$ among all patterns under study, while PRP showed the highest EPD $\left(296.54 \times \mathrm{E}+11 \mathrm{sej}^{-1} \cdot \mathrm{ha}^{-1} \cdot \mathrm{year}^{-1}\right)$. The impact of the intercropping system on the original planting pattern was not obvious. However, the addition of the grass-sheep subsystem had a significant effect on the emergy density in PRP.

As shown in Table 4, the emergy self-sufficiency ratio ESR ranged from 0.08 to 0.58 . CP, PRP, PGSP required more emergy than the other patterns. ESR of $\mathrm{CP}$ was also very low, which showed that both $\mathrm{CP}$ and PGSP required an external input. Because of the small effect of the addition of intercropping plants on the energy structure, ESR values for AP and ASP, PP and PPP were quite similar. ESR for PGSP was $33.3 \%$ lower than that for PRP.

Table 4. Emergy evaluation in the seven agroforestry planting patterns.

\begin{tabular}{|c|c|c|c|c|c|c|c|}
\hline Indices & $\mathrm{CP}$ & AP & ASP & PP & PPP & PRP & PGSP \\
\hline \multicolumn{8}{|l|}{ Emergy-power } \\
\hline $\begin{array}{l}\text { Density (EPD) } \\
(\times E+11)\end{array}$ & $18.20 \pm 4.92$ & $42.04 \pm 18.26$ & $42.91 \pm 17.51$ & $37.38 \pm 4.66$ & $38.59 \pm 3.98$ & $296.54 \pm 11.53$ & $220.74 \pm 50.88$ \\
\hline Emergy & & & & & & & \\
\hline $\begin{array}{l}\text { Self-sufficiency Ratio } \\
\text { (ESR) }\end{array}$ & $0.15 \pm 0.05$ & $0.58 \pm 0.20$ & $0.56 \pm 0.19$ & $0.55 \pm 0.06$ & $0.53 \pm 0.05$ & $0.12 \pm 0.01$ & $0.08 \pm 0.02$ \\
\hline $\begin{array}{l}\text { Emergy Yield Ratio } \\
\text { (EYR) }\end{array}$ & $0.99 \pm 0.06$ & $2.70 \pm 1.03$ & $2.51 \pm 0.87$ & $2.22 \pm 0.34$ & $2.14 \pm 0.25$ & $2.41 \pm 0.58$ & $3.52 \pm 0.82$ \\
\hline $\begin{array}{c}\text { Environmental } \\
\text { loading Ratio (ELR) }\end{array}$ & $1.30 \pm 0.0 .05$ & $14.63 \pm 6.34$ & $14.96 \pm 6.06$ & $12.69 \pm 1.09$ & $13.13 \pm 0.92$ & $13.80 \pm 2.26$ & $4.95 \pm 0.93$ \\
\hline $\begin{array}{l}\text { Emergy Restoration } \\
\text { Ratio (ERR) }\end{array}$ & $4.64 \pm 1.78$ & $1.10 \pm 0.60$ & $1.04 \pm 0.55$ & $1.14 \pm 1.03$ & $1.08 \pm 0.89$ & $0.41 \pm 0.01$ & $0.62 \pm 0.15$ \\
\hline $\begin{array}{l}\text { Emergy Benefit Ratio } \\
\text { (EBR) }\end{array}$ & $5.63 \pm 1.80$ & $3.80 \pm 1.64$ & $3.55 \pm 1.42$ & $3.36 \pm 1.36$ & $3.22 \pm 1.14$ & $2.82 \pm 0.58$ & $4.17 \pm 0.89$ \\
\hline $\begin{array}{l}\text { Emergy Sustainability } \\
\text { Index (ESI) }\end{array}$ & $0.76 \pm 0.02$ & $0.22 \pm 0.13$ & $0.20 \pm 0.11$ & $0.18 \pm 0.04$ & $0.16 \pm 0.03$ & $0.18 \pm 0.06$ & $0.74 \pm 0.28$ \\
\hline
\end{tabular}

The emergy yield ratio (EYR) ranged from 0.99 to 3.52 across patterns (Table 4); ESR for AP was $17.8 \%$ higher than that for PP, while the grass-sheep subsystem increased EYR by $46.1 \%$.

The environmental loading ratio (ELR) for CP and PGSP were lowest and highest across patterns, respectively (Table 4); ELR values for AP, ASP, PP, PPP, PRP demonstrated that these patterns depended heavily on non-renewable resources and low utilization of renewable resources, which may pose a great pressure on the environment. Adding the grass-sheep subsystem to PRP can significantly reduce as much as $64.1 \%$ of the environmental load.

The highest and lowest values for the emergy restoration ratio (ERR) among all patterns were found for CP and PRP, respectively (Figure 3). The addition of a subsystem to PRP increased ERR 
by 51.2\%; ERR calculated for PGSP (0.64) was much lower than for CP (4.64), which indicated that the control effect of rocky desertification was very unsatisfactory. The control benefits of rocky desertification in the other patterns do not seem to be as good as in CP.

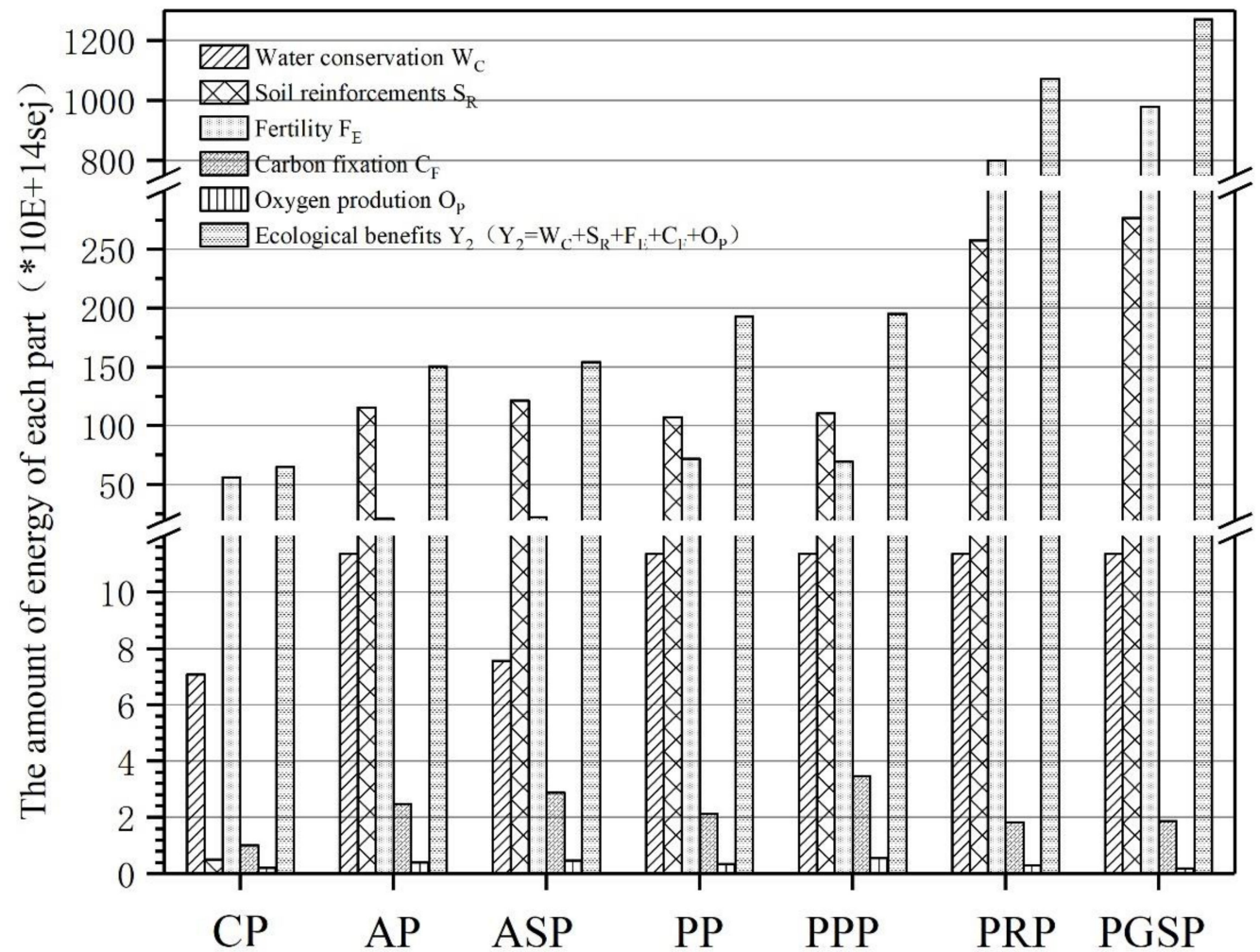

Figure 3. Ecological benefits of the seven typical agroforestry planting patterns.

The emergy benefit ratio (EBR) for $\mathrm{CP}$ (5.63) was the highest among all patterns studied, while that for PRP (2.82) was the lowest. Calculated EBR values for AP and PP were 3.80 and 3.36, respectively, which was also higher than that of PRP. The addition of intercropped plants in AP and PP slightly reduced EBR. However, the addition of the grass-sheep subsystem in PRP significantly increased EBR by up to $47.9 \%$, which may reduce the external inputs and result in high ecological efficiency and emergy output.

The emergy sustainability index (ESI) can be broadly divided into two categories for all seven patterns under study here; these include higher ESI values for CP and PGSP, lower ESI values for AP, ASP, PP, PRP. Compared with the simple planting pattern, the intercropping pattern had little effect on ELR and EYR. The addition of the grass-sheep subsystem to PRP enhanced EYR and significantly reduced ELR. The ESI in PGSP increased by $311.1 \%$ over that of PRP.

\subsection{Economic Benefit from the Seven Typical Agroforestry Planting Patterns}

Irrespective of free input, economic input from highest to lowest ranked as follows: PRP > PGSP $>$ ASP $>$ PPP $>$ AP $>$ PP $>$ CP (Table 5). On the other hand, if free input is taken into consideration, the ranking is as follows: $\mathrm{PGSP}>\mathrm{PRP}>\mathrm{PPP}>\mathrm{PP}>\mathrm{ASP}>\mathrm{AP}>\mathrm{CP}$. 
Table 5. Indices for the economic evaluation of the seven agroforestry planting patterns.

\begin{tabular}{|c|c|c|c|c|c|c|c|}
\hline Indices & $\mathrm{CP}$ & AP & ASP & PP & PPP & PRP & PGSP \\
\hline $\begin{array}{l}\text { Input with } \mathrm{I}_{\mathrm{f}}(\mathrm{I}) \text { (yuan } \\
\text { year }^{-1} \mathrm{ha}^{-1} \text { ) }\end{array}$ & $27,145.83$ & $28,034.67$ & $30,521.33$ & $32,374.33$ & $34,386.83$ & $164,662.50$ & $212,679.33$ \\
\hline $\begin{array}{l}\text { Input without } \mathrm{I}_{\mathrm{f}}\left(\mathrm{I}_{a}\right) \\
\text { (yuan year }^{-1} \mathrm{ha}^{-1} \text { ) }\end{array}$ & 5379.17 & $24,140.67$ & 25,324 & $23,183.33$ & $24,445.83$ & $83,908.33$ & $64,276.83$ \\
\hline $\begin{array}{l}\text { Output }(\mathrm{O}) \text { (yuan } \\
\text { year }{ }^{-1} \mathrm{ha}^{-1} \text { ) }\end{array}$ & $12,650.00$ & $111,890.00$ & $117,033.33$ & $107,083.33$ & $13,7402.08$ & $520,000.00$ & $583,250.00$ \\
\hline $\begin{array}{l}\text { Economic Output } \\
\text { /Input with } \mathrm{I}_{f}(\mathrm{O} / \mathrm{I})\end{array}$ & $0.46 \pm 0.06$ & $4.72 \pm 1.22$ & $4.25 \pm 0.80$ & $3.33 \pm 0.71$ & $4.03 \pm 0.80$ & $3.15 \pm 0.78$ & $2.72 \pm 0.52$ \\
\hline $\begin{array}{c}\text { Economic } \\
\text { Output/Input } \\
\text { without } \mathrm{I}_{f}(\mathrm{O} / \mathrm{I})\end{array}$ & $2.36 \pm 0.12$ & $5.5 \pm 1.43$ & $5.23 \pm 1.08$ & $4.73 \pm 1.22$ & $5.77 \pm 1.43$ & $6.17 \pm 1.53$ & $9.04 \pm 1.98$ \\
\hline $\begin{array}{l}\text { Unit economic benefit } \\
(\text { EBU, O-I) (yuan } \\
\left.\text { year }^{-1} \mathrm{ha}^{-1}\right)\end{array}$ & $\begin{array}{c}7270.8 \pm \\
2406.25\end{array}$ & $\begin{array}{c}83,855.33 \pm \\
46,050.60\end{array}$ & $\begin{array}{l}86,512 \pm \\
46,761.43\end{array}$ & $\begin{array}{l}74,709 \pm \\
24,596.39\end{array}$ & $\begin{array}{c}103,015.25 \pm \\
26,618.89\end{array}$ & $\begin{array}{c}355,337.5 \pm \\
131,544.00\end{array}$ & $\begin{array}{c}370,570.67 \pm \\
130,768.10\end{array}$ \\
\hline $\begin{array}{l}\text { Unit net economic } \\
\text { benefit }\left(\mathrm{EPBU}^{\mathrm{O}} \mathrm{O}-\mathrm{I}_{a} \text { ) }\right. \\
\left(\text { yuan year }^{-1} \mathrm{ha}^{-1} \text { ) }\right.\end{array}$ & $\begin{array}{c}14,495.83 \pm \\
2296.48\end{array}$ & $\begin{array}{c}87,749.33 \pm \\
49,540.65\end{array}$ & $\begin{array}{c}91,709.33 \pm \\
50,109.60\end{array}$ & $\begin{array}{l}83,900 \pm \\
25,640.93\end{array}$ & $\begin{array}{c}112,956.25 \pm \\
27,539.48\end{array}$ & $\begin{array}{l}436,091.67 \pm \\
136,716.63\end{array}$ & $\begin{array}{c}518,973.17 \pm \\
141,696.23\end{array}$ \\
\hline
\end{tabular}

Note: $\mathrm{O}$ is the economic output of the systems. I is the economic input of the systems. $\mathrm{I}_{a}$ is the actual economic input of the systems, $I_{f}$ is the input for free of the systems (the labor from the farmers and the poultry manure from the breeding subsystem) which was converted to the market value. $I=I_{a}+I_{f}$.

Economic output from CP was lowest (1265.00 yuan $\cdot \mathrm{year}^{-1} \mathrm{ha}^{-1}$ ) among all patterns studied, representing only $11.8 \%$ of PP and $2.2 \%$ of PGSP. When free investment was considered, output from $\mathrm{CP}$ was $46.6 \%$ of the corresponding input. With increasing investment, the economic output from PPP was $28.3 \%$ higher than that from PP, while the output from ASP increased by $4.6 \%$ over that from AP. Compared to PP, PGSP reduced external investment in purchases and increased input of farmer labor and free fertilizer by $12.2 \%$ of the output. The interplanting of pumpkin and the addition of the grass-sheep subsystem improved economic benefit (Table 5).

Compared to AP, ASP shows a reduced Economic Output/Input when free investment is considered. Conversely, compared to PP, PPP showed an increased Economic Output/Input when free investment was considered. Compared to PRP, the Economic Output/Input for PGSP was reduced by $13.6 \%$ when free input was considered. When free input was not considered, the Economic Output/Input for PGSP increased by $46.5 \%$. In both cases, CP showed the lowest Economic Output/Input among the seven patterns. In this case, when free investment was considered, the Economic Output/Input was only 0.46, which indicated that the economic revenue from CP was mainly the marketing return for free farmer labor and free fertilizer. The observed pattern ranking based on Economic benefit per unit and Economic pure benefit per unit was the following: PGSP > $\mathrm{PRP}>\mathrm{PPP}>\mathrm{ASP}>\mathrm{AP}>\mathrm{PP}>\mathrm{CP}$.

\subsection{Scenario Analysis of Seven Typical Agroforestry Planting Patterns}

Based on the scenario setting and pattern evaluation, the economic output is the major concern in the government promotion plan (Table 6). In the basic scenario, the total economic benefit from cultivation of pomegranate, corn, apple and pear in Mengzi City would increase by $8.8 \%$, while the total ecological benefits remain unchanged. In the improvement scenario, the corn planting area would be transformed into pomegranate and apple orchards, while the transformation of PRP, AP and PP into ecological planting patterns would be promoted. The total economic benefit would increase by $16.1 \%$ while the total ecological benefits would increase by $6.2 \%$. In this process, the corn planting area would decrease from 13,333 ha to $12,400 \mathrm{ha},(-7 \%)$. Finally, in the optimization scenario, the improvement of economic benefits and ecological benefits would be significant. In the promotion plan of the planting pattern, the area of all planting patterns would increase, while these patterns would all have better economic benefits. The current government promotion plan would not significantly improve the ecological benefits. With an increase of ecological planting patterns, the economic and ecological benefits would be further improved. The patterns under study here cannot improve the ecological and economic benefits equally. 
Table 6. Emergy and economic status after five years under each scenario constructed.

\begin{tabular}{|c|c|c|c|c|c|c|c|}
\hline Scenario & $\begin{array}{l}\text { Total planting } \\
\text { area (ha) }\end{array}$ & $\begin{array}{c}\text { Total net economic } \\
\text { benefit } \\
\text { (yuan year }^{-1} \mathrm{ha}^{-1} \text { ) }\end{array}$ & EACI (\%) & $\begin{array}{c}\text { Total economic } \\
\text { benefit } \\
\text { (yuan year }{ }^{-1} \mathrm{ha}^{-1} \text { ) }\end{array}$ & EACI (\%) & $\begin{array}{c}\text { Total ecological } \\
\text { benefit } \\
\text { (sej year }{ }^{-1} \text { ha }^{-1} \text { ) }\end{array}$ & EACI (\%) \\
\hline $\begin{array}{l}\text { Current } \\
\text { situation }\end{array}$ & 30,799 & $3,527,170,867$ & & $4,600,534,572$ & & $1.37953 \times 10^{21}$ & \\
\hline $\begin{array}{l}\text { Baseline } \\
\text { scenario }\end{array}$ & 33,000 & $4,136,793,863$ & 9.4 & $5,362,392,475$ & 8.8 & $1.5866 \times 10^{21}$ & 0.2 \\
\hline $\begin{array}{l}\text { Improvement } \\
\text { scenario }\end{array}$ & 33,000 & $4,435,287,213$ & 17.4 & $5,725,326,213$ & 16.1 & $1.68236 \times 10^{21}$ & 6.2 \\
\hline $\begin{array}{l}\text { Optimization } \\
\text { scenario }\end{array}$ & 33,000 & $4,900,887,703$ & 29.7 & $6,326,987,305$ & 28.4 & $1.85222 \times 10^{21}$ & 17.0 \\
\hline
\end{tabular}

EACI: Equal area change of the index. In the current government planning adjustment, the planting area has increased. In order to eliminate the numerical difference caused by the increase in area, the indicators are specifically converted into the current area for comparison.

\section{Discussion}

The results presented herein showed that the four basic patterns (CP, AP, PP, PRP) were different in performance, according to emergy analysis (Tables 3 and 4). The AP pattern showed lower EPD, EYR, ELR, higher ESI, which is in stark contrast to the PRP pattern. While the former represents a traditional pattern with less manual interference, low input, low output, low pressure, the pomegranate market is competitive, prices vary greatly. Local farmers had to become more industry-oriented while planting pomegranate, thus resorting to new practice, such as bagging, investing more in labor and non-renewable resources. Although different types of resources and input forms were required in these patterns, labor and fertilizer dominated the major contribution to the total input, which was consistent with the China's crop production system [40].

The emergy for the CP pattern in the study area differed from other studies on corn in Yunnan [41]. EYR and ELR were higher than the corresponding values for Danish traditional feed corn production method [42], for the Guangxi Duan Agricultural Ecological Economic System in the karst area [43]. The difference may be due to the more serious rocky desertification and the lower planting density in our study area. The ELR for the PRP pattern was much higher than that in the Duan area, which in turn is higher than that in Guizhou Province [44]. This difference may due to the long history of pomegranate cultivation in the study area, the large single-headed planting area, the reasonable level of management and fertilization. The gap between the AP and the PP patterns is very small. The overall emergy and the economic indicator for AP are slightly better than those for PP. The EYR value obtained by Zhang et al. $[45,46]$ in Dengcheng County in Shaanxi Province was relatively consistent with 2.69, while the ELR value calculated in this study was much higher than that by Zhang et al. for a different apple planting density and another apple genotype.

In compound agroforestry planting patterns, the contribution from both and PPP to the original respective patterns were relatively limited. The emergy indicators for these two patterns decreased, because the intercropping pattern requires more input of fertilizers and pesticides. The utilization efficiency of natural resources of the whole system decreased, the shading of light make the less growth in intercropping crops than that in monoculture [47]. The economic indicators of ASP and PPP showed that the intercropping of pear and pumpkin had a better collaborative utilization of resources. Comparing with PRP, the emergy of PGSP was significantly improved, which was similar as the previous report [48]. Except for the deterioration of the ESR, other indicators have greatly improved. Compared with Pig-Marsh-Pomegranate pattern in the rural area of Linyi City, Shandong Province [47], ESR, ELR, EYR calculated here were lower because the biogas system contributes to the recycling of manure and urine at a high resource utilization rate. At the same time, local government subsidy to Pig-Marsh-Pomegranate pattern reduces investment. Compared with the overall evaluation of results in Shandong Province, the EYR index for all patterns under study here was lower than, because the conditions for agricultural production in the karst region are poorer than in non-karst regions [49]. 
The ELR values calculated here for AP, ASP, PP, PPP, PRP were all higher than the overall level for Yunnan Province [50], which indicated that, in this study, these patterns showed higher pressure on the environment than the average load in Yunnan Province. Our data is inconsistent with the orientation of the agricultural planting pattern and needs to be improved as soon as possible. The ELR values for $\mathrm{CP}$ and PGSP are lower than the overall level for Yunnan Province, the pressure on the environment is appropriate. In addition, the values of ESI are similar to that of ELR. The ESI values for AP, ASP, PP, PPP, PRP are much lower than that for the overall level in Yunnan Province, while ESI values for CP and PGSP are slightly higher than overall level in the province.

Compared to the evaluation of national energy production (maize, wheat, rice, soybean; EYR > 1.45, ELR > 4.50, ESI < 0.33), the EYR and ELR values for CP in this study were lower than the corresponding values for these other four grain production patterns in 2015, while the ESI value was much higher [51]. This difference may be due to the influence of the study area and karst topography, the scale of corn cultivation, on EYR and ELR values. At the same time, the ESI value is consistent with those of maize, wheat and rice, while both, EYR and ELR are approximately twice the value for maize, wheat, rice at national level. Compared with simple grain production patterns, fruit cultivation has a relatively high-input and high-output pattern, better emergy performance. EYR, ELR and ESI values of PGSP were twice as high as those of soybean, indicating that PGSP was superior to all grain production patterns in terms of emergy performance. In addition, ESI, EYR of PGSP was significantly lower than that of biogas-linked pattern [47,52], while EYR was higher than that of greenhouse linked pattern [53]. However, due to the lack of analysis of specific economic indicators in previous studies, it is impossible to make a more comprehensive comparison of economic and ecological benefits with this study. As far as results from our study are concerned, PGSP achieved very good performance, while AP, ASP, PP, PPP, PRP currently show some deficiencies in terms of emergy and economic performance that need to be corrected.

The overall performance of corn in the karst region in Yunnan Province is poor; therefore, we propose that the government should advocate the reduction of corn planting. Additionally, although PPP and ASP perform better than corn, the local government needs to introduce appropriate breeding systems to optimize current ASP and PPP [54]. Similarly, PGSP shows attractive ecological and economic benefits, it is still necessary to improve the ratio value for a scientifically standardized aquaculture subsystem in the existing PGSP. Castellini's research on two poultry farms in Italy showed that the adding of grazing to traditional orchard was similar with PGSP [55]. At the same time, it is desirable to attempt the introduction of a biogas system to reuse the increasing stock waste $[56,57]$. Because apples, pears, pomegranates together comprise a relatively long harvest period, the local government should also coordinate the establishment of a temporary labor market to meet the demand for labor.

Our scenario analysis allowed a better understanding of potential ecological and economic benefits under a better planting structure configuration. According to current government plans, after five years, the economy and ecology of the different agroforestry planting patterns studied here will have increased differentially. Therefore, we suggest that the government makes greater efforts in the allocation and improvement of these patterns.

Additionally, although our research has drawn some suggestions on these seven patterns, we still need to carry out multi-year observation on the sample land in multiple regions [58,59], In the future research, the geographic information system, emergetic ternary diagrams and other methods may be used to guide the pattern improvement and agricultural planning at regional scale [60]. At the same time, there is still a need to investigate ecosystem sustainability, driving force and biodiversity change at different scales combining existing models [61-63].

Overall, emergy analysis used in this study made full consideration of all aspects, from agricultural production to consumption and utilization of natural resources; thus, it included the more objective input and output analysis of the agricultural production process and hence, a more reasonable sustainability analysis of each ecological economic system [64]. Further, we realize that the actual 
energy conversion rates may be biased for the differences in natural conditions, as well as social and economic development and productivity levels [65]. Thus, future research should focus on the ecological economic system of energy-conversion efficiency in the karst region for proper correction of available energy-conversion rates to assess the ecological systems and possible economic development.

\section{Conclusions}

At the ecosystem scale, the economic benefits of the remaining six agroforestry planting patterns were significantly better than the traditional corn pattern. The ecological benefits of AP and PP did not increase after intercropping was added. After added subsystem of grass + sheep to these patterns, the ecological and economic benefits of PGSP were obviously improved. At the regional scale, scenario analysis indicated that the existing government planning is purely economic oriented. After the transformation of existing patterns to ecological agroforestry planting patterns (ASP, PPP and PGSP), the government and farmers can get better economic and ecological benefits.

Author Contributions: Conceptualization, H.Z. and Z.Z. (Zhigang Zou); methodology, K.W. and F.Z. (Fuping Zeng); investigation, H.Z., H.D., F.Z. (Fang Zhang) and Z.Z. (Zhaoxia Zeng); writing-original draft preparation, H.Z. and Z.Z. (Zhigang Zou); writing-review and editing, H.Z. and Z.Z. (Zhigang Zou); funding acquisition, F.Z. (Fuping Zeng).

Funding: This research was funded by the National Key Research and Development Program (2016YFC0502505, 2016YFC0502400); National Science and Technology Support Plan (2015BAD06B04); National Natural Science Foundation of China (31870712); Guangxi Innovation-driven Development Program (AA18118015), Guangxi Key Research and Development Program (AB17129002, AB17292064, AB17129009), Innovation Research Team Project of Institute of Subtropical Agriculture, Chinese academy of sciences (2017QNCXTD_XXL) and Guangxi Provincial Program of Distinguished Experts in China.

Acknowledgments: We acknowledge the technical and field work support from Jianyun Zhang, Jiejun Zhao, Songlian Bao.

Conflicts of Interest: The authors declare no conflict of interest. 


\section{Appendix A}

Table A1. Emergy analysis table of the CP in 2017(/ha/year).

\begin{tabular}{|c|c|c|c|c|c|c|c|c|}
\hline \multirow{2}{*}{ Item } & \multicolumn{3}{|c|}{ Raw Amounts } & \multirow{2}{*}{$\begin{array}{c}\text { EUVs } \\
\left.\text { (sej unit }^{-1}\right)\end{array}$} & \multicolumn{3}{|c|}{ Solar Emergy (sej) } & \multirow{2}{*}{$\begin{array}{c}\text { Average } \\
\text { (sej) }\end{array}$} \\
\hline & 1 & 2 & 3 & & 1 & 2 & 3 & \\
\hline \multicolumn{9}{|l|}{ Input } \\
\hline \multicolumn{9}{|l|}{ Renewable resource (R) } \\
\hline Solar radiation $(\mathrm{J})$ & $5.09 \times 10^{13}$ & $5.09 \times 10^{13}$ & $5.09 \times 10^{13}$ & 1 & $5.09 \times 10^{13}$ & $5.09 \times 10^{13}$ & $5.09 \times 10^{13}$ & $5.09 \times 10^{13}$ \\
\hline Wind $(\mathrm{J})$ & $7.51 \times 10^{11}$ & $7.51 \times 10^{11}$ & $7.51 \times 10^{11}$ & 1900 & $1.43 \times 10^{15}$ & $1.43 \times 10^{15}$ & $1.43 \times 10^{15}$ & $1.43 \times 10^{15}$ \\
\hline Rain (chemical) (J) & $4.83 \times 10^{10}$ & $4.83 \times 10^{10}$ & $4.83 \times 10^{10}$ & 23,500 & $1.13 \times 10^{15}$ & $1.13 \times 10^{15}$ & $1.13 \times 10^{15}$ & $1.13 \times 10^{15}$ \\
\hline Water (for irrigation) (J) & & & & & & & & \\
\hline Subtotal, $\mathrm{R}=$ Rain + Water & & & & & $2.61 \times 10^{15}$ & $2.61 \times 10^{15}$ & $2.61 \times 10^{15}$ & $2.61 \times 10^{15}$ \\
\hline \multicolumn{9}{|l|}{ Nonrenewable resource $(\mathrm{N})$} \\
\hline \multicolumn{9}{|l|}{ Loss of topsoil } \\
\hline Total N (g) & 2580 & 2580 & 2580 & $464,000,000[18]$ & $1.20 \times 10^{12}$ & $1.20 \times 10^{12}$ & $1.20 \times 10^{12}$ & $1.20 \times 10^{12}$ \\
\hline Total P (g) & 2280 & 2280 & 2280 & $5.07 \times 10^{9}[18]$ & $1.16 \times 10^{13}$ & $1.16 \times 10^{13}$ & $1.16 \times 10^{13}$ & $1.16 \times 10^{13}$ \\
\hline Total K (g) & 58,000 & 58,000 & 58,000 & $1.31 \times 10^{9}$ & $7.60 \times 10^{13}$ & $7.60 \times 10^{13}$ & $7.60 \times 10^{13}$ & $7.60 \times 10^{13}$ \\
\hline Organic (J) & $557,000,000$ & $557,000,000$ & $557,000,000$ & $94,100[66]$ & $5.24 \times 10^{13}$ & $5.24 \times 10^{13}$ & $5.24 \times 10^{13}$ & $5.24 \times 10^{13}$ \\
\hline $\begin{array}{c}\text { Subtotal (Total N + Total P + } \\
\text { Total K + Organic) }\end{array}$ & & & & & $1.41 \times 10^{14}$ & $1.41 \times 10^{14}$ & $1.41 \times 10^{14}$ & $1.41 \times 10^{14}$ \\
\hline Local resource $(\mathrm{I}), \mathrm{I}=\mathrm{R}+\mathrm{N}$ & & & & & $2.75 \times 10^{15}$ & $2.75 \times 10^{15}$ & $2.75 \times 10^{15}$ & $2.75 \times 10^{15}$ \\
\hline Purchased renewable resource $\left(F_{R}\right)$ & & & & & & & & \\
\hline Labor $(10 \%)^{\#}(\mathrm{~J})$ & $21,800,000$ & $58,000,000$ & $13,100,000$ & $2,200,000[67]$ & $4.79 \times 10^{13}$ & $1.28 \times 10^{14}$ & $2.87 \times 10^{13}$ & $6.81 \times 10^{13}$ \\
\hline Manure $(68 \%)^{\# \#}(\mathrm{~J})$ & $1.79 \times 10^{11}$ & $7.67 \times 10^{10}$ & $1.92 \times 10^{11}$ & 35,000 & $6.26 \times 10^{15}$ & $2.68 \times 10^{15}$ & $6.71 \times 10^{15}$ & $5.22 \times 10^{15}$ \\
\hline Subtotal & & & & & $6.31 \times 10^{15}$ & $2.81 \times 10^{15}$ & $6.74 \times 10^{15}$ & $5.28 \times 10^{15}$ \\
\hline \multicolumn{9}{|l|}{ Purchased nonrenewable resource $\left(\mathrm{F}_{\mathrm{N}}\right)$} \\
\hline Seeds of corn (yuan) & 825 & 750 & 825 & $1.21 \times 10^{12}$ & $9.98 \times 10^{14}$ & $9.08 \times 10^{14}$ & $9.98 \times 10^{14}$ & $9.68 \times 10^{14}$ \\
\hline Labor $(90 \%)^{\#}(\mathrm{~J})$ & $1.96 \times 10^{8}$ & $5.22 \times 10^{8}$ & $1.17 \times 10^{8}$ & $2,200,000[67]$ & $4.31 \times 10^{14}$ & $1.15 \times 10^{15}$ & $2.58 \times 10^{14}$ & $6.12 \times 10^{14}$ \\
\hline Compound fertilizer $(\mathrm{kg})$ & 1650 & 1000 & 2000 & $3.56 \times 10^{12}[17]$ & $5.87 \times 10^{15}$ & $3.56 \times 10^{15}$ & $7.12 \times 10^{15}$ & $5.52 \times 10^{15}$ \\
\hline Manure $(32 \%))^{\# \#(J)}$ & $8.42 \times 10^{10}$ & $3.61 \times 10^{10}$ & $9.02 \times 10^{10}$ & $35,000[17]$ & $2.95 \times 10^{15}$ & $1.26 \times 10^{15}$ & $3.16 \times 10^{15}$ & $2.46 \times 10^{15}$ \\
\hline Pesticide (yuan) & 1800 & 375 & 2000 & $4.37 \times 10^{11 *}$ & $7.87 \times 10^{14}$ & $1.64 \times 10^{14}$ & $8.74 \times 10^{14}$ & $6.08 \times 10^{14}$ \\
\hline Subtotal & & & & & $1.10 \times 10^{16}$ & $7.04 \times 10^{15}$ & $1.24 \times 10^{16}$ & $1.02 \times 10^{16}$ \\
\hline Purchased resource $(F), F=F_{R}+F_{N}$ & & & & & $1.73 \times 10^{16}$ & $9.85 \times 10^{15}$ & $1.91 \times 10^{16}$ & $1.54 \times 10^{16}$ \\
\hline Total input (U), $\mathrm{U}=\mathrm{I}+\mathrm{F}$ & & & & & $2.01 \times 10^{16}$ & $1.26 \times 10^{16}$ & $2.19 \times 10^{16}$ & $1.82 \times 10^{16}$ \\
\hline Yield $\left(Y_{1}\right)$ & 13,200 & 8250 & 16,500 & $1.21 \times 10^{12}$ & $1.60 \times 10^{16}$ & $9.98 \times 10^{15}$ & $2.00 \times 10^{16}$ & $1.53 \times 10^{16}$ \\
\hline $\begin{array}{c}\text { Ecological benefits }\left(\mathrm{Y}_{2}\right) \\
\text { Water conservation }\left(\mathrm{W}_{\mathrm{C}}\right) \\
\text { Soil reinforcement }\left(\mathrm{S}_{\mathrm{R}}\right)\end{array}$ & $3.01 \times 10^{10}$ & $3.01 \times 10^{10}$ & $3.01 \times 10^{10}$ & 23,500 & $7.07 \times 10^{14}$ & $7.07 \times 10^{14}$ & $7.07 \times 10^{14}$ & $7.07 \times 10^{14}$ \\
\hline
\end{tabular}


Table A1. Cont.

\begin{tabular}{|c|c|c|c|c|c|c|c|c|}
\hline \multirow{2}{*}{ Item } & \multicolumn{3}{|c|}{ Raw Amounts } & \multirow{2}{*}{$\begin{array}{c}\text { EUVs } \\
\text { (sej unit }^{-1} \text { ) }\end{array}$} & \multicolumn{3}{|c|}{ Solar Emergy (sej) } & \multirow{2}{*}{$\begin{array}{l}\text { Average } \\
\text { (sej) }\end{array}$} \\
\hline & 1 & 2 & 3 & & 1 & 2 & 3 & \\
\hline Total N (g) & 902 & 902 & 902 & $4.64 \times 10^{8}[18]$ & $4.18 \times 10^{11}$ & $4.18 \times 10^{11}$ & $4.18 \times 10^{11}$ & $4.18 \times 10^{11}$ \\
\hline Total P (g) & 799 & 799 & 799 & $5.07 \times 10^{9}[18]$ & $4.05 \times 10^{12}$ & $4.05 \times 10^{12}$ & $4.05 \times 10^{12}$ & $4.05 \times 10^{12}$ \\
\hline Total K (g) & 20,300 & 20,300 & 20,300 & $1.31 \times 10^{9}$ & $2.66 \times 10^{13}$ & $2.66 \times 10^{13}$ & $2.66 \times 10^{13}$ & $2.66 \times 10^{13}$ \\
\hline Organic (J) & $1.95 \times 10^{8}$ & $1.95 \times 10^{8}$ & $1.95 \times 10^{8}$ & $94,100[66]$ & $1.83 \times 10^{13}$ & $1.83 \times 10^{13}$ & $1.83 \times 10^{13}$ & $1.83 \times 10^{13}$ \\
\hline & & & & & $4.94 \times 10^{13}$ & $4.94 \times 10^{13}$ & $4.94 \times 10^{13}$ & $4.94 \times 10^{13}$ \\
\hline \multicolumn{9}{|l|}{ Fertility $\left(\mathrm{F}_{\mathrm{E}}\right)$} \\
\hline Total N (g) & 600,000 & 493,000 & 606,000 & $4.64 \times 10^{8}[18]$ & $2.78 \times 10^{14}$ & $2.29 \times 10^{14}$ & $2.81 \times 10^{14}$ & $2.63 \times 10^{14}$ \\
\hline Total P (g) & 920,000 & 385,000 & 971,000 & $5.07 \times 10^{9}[18]$ & $4.66 \times 10^{15}$ & $1.95 \times 10^{15}$ & $4.92 \times 10^{15}$ & $3.85 \times 10^{15}$ \\
\hline Total K (g) & 169,000 & 25,600 & 119,000 & $1.31 \times 10^{9}$ & $2.22 \times 10^{14}$ & $3.35 \times 10^{13}$ & $1.55 \times 10^{14}$ & $1.37 \times 10^{14}$ \\
\hline Organic (J) & $1.43 \times 10^{10}$ & $1.43 \times 10^{10}$ & $1.43 \times 10^{10}$ & $94,100[66]$ & $1.35 \times 10^{15}$ & $1.35 \times 10^{15}$ & $1.35 \times 10^{15}$ & $1.35 \times 10^{15}$ \\
\hline subtotal & & & & & $6.51 \times 10^{15}$ & $3.56 \times 10^{15}$ & $6.71 \times 10^{15}$ & $5.59 \times 10^{15}$ \\
\hline Carbon fixation $\left(\mathrm{C}_{\mathrm{F}}\right)(\mathrm{g})$ & $17,500,000$ & $13,800,000$ & $17,000,000$ & $6,190,000[18]$ & $1.09 \times 10^{14}$ & $8.53 \times 10^{13}$ & $1.05 \times 10^{14}$ & $9.97 \times 10^{13}$ \\
\hline Oxygen production $\left(\mathrm{O}_{\mathrm{P}}\right)(\mathrm{g})$ & $14,300,000$ & $16,900,000$ & $20,800,000$ & $1,220,000[18]$ & $1.75 \times 10^{13}$ & $2.06 \times 10^{13}$ & $2.54 \times 10^{13}$ & $2.12 \times 10^{13}$ \\
\hline $\begin{array}{c}\text { Total } \mathrm{Y}_{2}=\underset{\mathrm{C}}{\mathrm{W}_{\mathrm{C}}}+\mathrm{S}_{\mathrm{R}}+\mathrm{F}_{\mathrm{E}}+\mathrm{C}_{\mathrm{F}}+\mathrm{O}_{\mathrm{P}} \\
\text { Indices }\end{array}$ & & & & & $7.39 \times 10^{15}$ & $4.43 \times 10^{15}$ & $7.59 \times 10^{15}$ & $6.47 \times 10^{15}$ \\
\hline Em-Power Density (EPD) & & & & & $2.01 \times 10^{12}$ & $1.26 \times 10^{12}$ & $2.19 \times 10^{12}$ & $1.82 \times 10^{12}$ \\
\hline Emergy Self-sufficiency Ratio (ESR) & & & & & 0.14 & 0.22 & 0.13 & 0.15 \\
\hline Emergy Exchange Ratio (EER) & & & & & 0.86 & 0.88 & 0.79 & 0.84 \\
\hline Emergy Yield Ratio (EYR) & & & & & 0.92 & 1.01 & 1.04 & 0.99 \\
\hline Environmental Loading Ratio (ELR) & & & & & 1.25 & 1.32 & 1.34 & 1.30 \\
\hline Emergy Restoration Ratio (ERR) & & & & & 0.43 & 0.45 & 0.40 & 0.42 \\
\hline Emergy Benefit Ratio (EBR) & & & & & 1.35 & 1.46 & 1.44 & 1.41 \\
\hline Emergy Sustainability Index (ESI) & & & & & 0.74 & 0.77 & 0.78 & 0.76 \\
\hline $\begin{array}{l}\text { Emergy Index for Sustainable } \\
\text { Development (EISD) }\end{array}$ & & & & & 0.63 & 0.67 & 0.62 & 0.63 \\
\hline
\end{tabular}

* EMR (Emergy Money Ratio) was deduced by the linear correlation between the emergy/money ratio and GDP as the Chinese GDP smoothing index of year 2005-2013 is 2.155 and

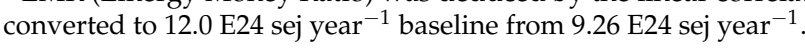


Table A2. Economical raw amounts of the CP in 2017 (/ha/year).

\begin{tabular}{|c|c|c|c|c|}
\hline \multirow{2}{*}{ Iterm } & \multicolumn{3}{|c|}{ Money (yuan) } & \multirow{2}{*}{$\begin{array}{c}\text { Average } \\
\text { (yuan) }\end{array}$} \\
\hline & 1 & 2 & 3 & \\
\hline \multicolumn{5}{|l|}{ Input(I) } \\
\hline \multicolumn{5}{|l|}{ Input for actual $\left(\mathrm{I}_{a}\right)$} \\
\hline Labor of purchased & 0.00 & 0.00 & 0.00 & 0.00 \\
\hline Seeds of corn & 825.00 & 750.00 & 825.00 & 800.00 \\
\hline Compound fertilizer & 3300.00 & 0.00 & 4000.00 & 2433.33 \\
\hline Nitrogenous fertilizer & 0.00 & 1012.50 & 0.00 & 337.50 \\
\hline Pesticide & 1800.00 & 375.00 & 2000.00 & 1391.67 \\
\hline Subtotal $\mathrm{I}_{\mathrm{a}}$ & 5925.00 & 2137.50 & 6825.00 & 4962.50 \\
\hline \multicolumn{5}{|l|}{ Input for free $\left(\mathrm{I}_{f}\right)$} \\
\hline Labor of farmers & 3000.00 & 8000.00 & 1800.00 & 4266.67 \\
\hline Manure & $21,000.00$ & 9000.00 & $22,500.00$ & $17,500.00$ \\
\hline Subtotal $\mathrm{I}_{\mathrm{f}}$ & $24,000.00$ & $17,000.00$ & $24,300.00$ & $21,766.67$ \\
\hline $\begin{array}{c}\text { Total input } \mathrm{I}=\mathrm{I}_{a}+\mathrm{I}_{f} \\
\text { Output }(\mathrm{O})\end{array}$ & \multicolumn{3}{|c|}{ Output (O) } & $26,729.17$ \\
\hline Corn & $13,200.00$ & 8250.00 & $16,500.00$ & $12,650.00$ \\
\hline $\begin{array}{l}\text { Total output } \\
\text { Indices }\end{array}$ & $13,200.00$ & 8250.00 & $16,500.00$ & $12,650.00$ \\
\hline Input with $\mathbf{I}_{\mathbf{f}}$ & $29,925.00$ & $19,137.50$ & $31,125.00$ & $26,729.17$ \\
\hline Input without $I_{f}$ & 5925.00 & 2137.50 & 6825.00 & 4962.50 \\
\hline Output & $13,200.00$ & 8250.00 & $16,500.00$ & $12,650.00$ \\
\hline Economic Output/Input with If (O/I) & 0.44 & 0.43 & 0.53 & 0.47 \\
\hline Economic Output/Input without If $\left(\mathrm{O} / \mathrm{I}_{a}\right)$ & 2.23 & 3.86 & 2.42 & 2.84 \\
\hline Economic benefit per unit (EBU, O-I) & $-16,725.00$ & $-10,887.50$ & $-14,625.00$ & $-14,079.17$ \\
\hline Economic pure benefit per unit (EPBU, $\mathrm{I}_{a}$ ) & 7275.00 & 6112.50 & 9675.00 & 7687.50 \\
\hline
\end{tabular}

\section{References}

1. Ying, B.; Xiao, S.Z.; Xiong, K.N.; Cheng, Q.W.; Luo, J.S. Comparative studies of the distribution characteristics of rocky desertification and land use/land cover classes in typical areas of Guizhou province, China. Environ. Earth Sci. 2014, 71, 631-645. [CrossRef]

2. Cao, J.H.; Yuan, D.X.; Tong, L.Q.; Mallik, A.; Yang, H.; Huang, F. An overview of karst ecosystem in southwest China: Current state and future Management. J. Resour. Ecol. 2015, 6, 247-256.

3. Chen, S.Z.; Zhou, Z.F.; Yan, L.H.; Li, B. Quantitative evaluation of ecosystem health in a karst area of south China. Sustainability 2016, 8, 975. [CrossRef]

4. Liu, H.Y.; Zhang, M.Y.; Lin, Z.S.; Xu, X.J. Spatial heterogeneity of the relationship between vegetation dynamics and climate change and their driving forces at multiple time scales in Southwest China. Agric. For. Meteorol. 2018, 256, 10-21. [CrossRef]

5. Peng, W.X.; Wang, K.L.; Song, T.Q.; Zeng, F.P.; Wang, J.R. Controlling and restoration models of complex degradation of vulnerable Karst ecosystem. Acta Ecol. Sina. 2008, 28, 811-820.

6. Zhang, M.Y.; Wang, K.L.; Liu, H.Y.; Wang, J.; Zhang, C.H.; Yue, Y.M.; Qi, X.K. Spatio-temporal variation and impact factors for vegetation carbon sequestration and oxygen production based on rocky desertification control in the karst region of Southwest China. Remote Sens. 2016, 8, 102. [CrossRef]

7. Tong, X.W.; Wang, K.L.; Brandt, M.; Yue, Y.M.; Liao, C.J.; Fensholt, R. Assessing future vegetation trends and restoration prospects in the karst regions of southwest China. Remote Sens. 2016, 8, 357. [CrossRef]

8. Zeng, F.P.; Wang, K.L. Effects of "Grain-for-Green" models in karst regions in Northwest Guangxi. Rural Eco-Environ. 2005, 21, 18-22.

9. Qin, Z.Q.; Lou, X.W.; Lei, H.Y. Controlling Karst Rocky Desertification by Developing Ecological Grassland Animal Husbandry in Anshun City, Guizhou. Guizhou. Agric. Sci. 2008, 36, 129-131.

10. Cui, L.; Xiong, K.L.; Guan, Z.H.; Chen, Y.H.; Liu, Z.Q. The model of karst land management based on plant diversity restoration and protection: Examples from Salaxi and Huajiang areas of Guizhou. Cars. Sin. 2016, 35, 513-524. 
11. Zhang, H.; Xiong, K.N.; Su, M.M.; Su, X.L.; Bai, X.M. Strategy Analysis of Control Project of Grassland and Animal Husbandry of Rocky Desertification Area in Karst Mountains Take Dingtan Drainage of Huajiang as an Example. Chin. J. Grassl. 2013, 35, 4-8.

12. Jia, X.; Fu, B.; Feng, X.; Hou, G.; Liu, Y.; Wang, X. The tradeoff and synergy between ecosystem services in the Grain-for-Green areas in Northern Shaanxi, China. Ecol. Indi. 2014, 43, 103-113. [CrossRef]

13. Vaast, P.; Somarriba, E. Trade-offs between crop intensification and ecosystem services: the role of agroforestry in cocoa cultivation. Agrofor. Syst. 2014, 88, 947-956. [CrossRef]

14. Zhang, J.; Wang, L.; Su, J. The Soil Water Condition of a Typical Agroforestry System under the Policy of Northwest China. Forests 2018, 9, 730. [CrossRef]

15. Liu, M.C.; Liu, X.C.; Yang, Z.S. An integrated indicator on regional ecological civilization construction in China. Int. J. Sustain. Dev. World Ecol. 2016, 23, 53-60. [CrossRef]

16. Lu, H.F.; Tan, Y.W.; Zhang, W.S.; Qiao, Y.C.; Campbell, D.E.; Zhou, L.; Ren, H. Integrated emergy and economic evaluation of lotus-root production systems on reclaimed wetlands surrounding the Pearl River Estuary, China. J. Clean Prod. 2017, 158, 367-379. [CrossRef] [PubMed]

17. Odum, H.T. Environmental accounting: EMERGY and environmental decision making; John Wiley: New York, NY, USA, 1996; pp. 76-152.

18. Campbell, D.E.; Lu, H.F.; Lin, B.L. Emergy evaluations of the global biogeochemical cycles of six biologically active elements and two compounds. Ecol. Model. 2014, 271, 32-51. [CrossRef]

19. Diemont, S.A.W.; Martin, J.F.; Levy-Tacher, S.I. Emergy evaluation of lacandon Maya indigenous swidden agroforestry in Chiapas, Mexico. Agrofor. Syst. 2005, 66, 23-42. [CrossRef]

20. Fonseca, A.M.P.; Marques, C.A.F.; Pinto-Correia, T.; Campbell, D.E. Emergy analysis of a silvo-pastoral system, a case study in southern Portugal. Agrofor. Syst. 2015, 90, 137-157. [CrossRef]

21. Tilley, D.R.; Comar, V. Emergy-based simulation to assess Brazil's long-term carrying capacity: environment, electricity and population. Popul. Env. 2006, 27, 307-326. [CrossRef]

22. Patrizi, N.; Niccolucci, V.; Castellini, C.; Pulselli, F.M.; Bastianoni, S. Sustainability of agro-livestock integration: Implications and results of Emergy evaluation. Sci Total Environ. 2018, 622-623, 1543-1552. [CrossRef] [PubMed]

23. Zou, Z.G.; Zhang, J.; Zeng, S.X.; Zhang, J.Y.; Zhao, J.J.; Bao, S.; Zeng, F.P. Emergy analysis of four typical planting modes in Karst faulted basins of Yunnan Province, China. Chin. J. Applied. Ecol. 2018, 29, 2641-2650. [CrossRef]

24. Houshyar, E.; Wu, X.F.; Chen, G.Q. Sustainability of wheat and maize production in the warm climate of southwestern Iran: An emergy analysis. J. Clean Prod. 2018, 172, 2246-2255. [CrossRef]

25. Tilley, D.R. Exploration of Odum's dynamic emergy accounting rules for suggested refinements. Ecol. Model. 2014, 279, 36-44. [CrossRef]

26. Vassallo, P.; Beiso, I.; Bastianoni, S.; Fabiano, M. Dynamic emergy evaluation of a fish farm rearing process. J. Environ Manage. 2009, 90, 2699-2708. [CrossRef] [PubMed]

27. Ren, J.M.; Zhang, L.; Wang, R.S. Measuring the sustainability of policy scenarios: Emergy-based strategic environmental assessment of the Chinese paper industry. Ecol. Complex. 2010, 7, 156-161. [CrossRef]

28. Li, S. Analysis on the sustainable development of typical Karst rocky desertification area based on emergy method. J. Arid. Land. Res. Environ. 2014, 28, 33-38.

29. Lu, Y.; Wei, Y.F.; Deng, X.L.; Wang, J. Dynamic analysis of emergy for agroecosystem in karst mountain area. J. Soil. Water. Cons. 2006, 20, 166-169.

30. Lin, D.; Yu, H.; Lian, F.; Wang, J.A.; Zhu, A.X.; Yue, Y.J. Quantifying the hazardous impacts of human-induced land degradation on terrestrial ecosystems: A case study of karst areas of south China. Environ. Earth Sci. 2016, 75, 18. [CrossRef]

31. Wu, J.H.; Mou, Q.; Tang, C.B.; Zhao, X.Y.; Zhang, D.Q.; Xie, G.W. Techniques for sheep raising through grass growing in rocky desertification mountain area. Prat. Sci. 2009, 26, 126-128.

32. Zhang, H.; Xiong, K.N.; Su, X.L. Practaculture current situation and its development response of Guizhou rocky desertification area. Adv. Environ Sci. Eng. 2012, 518-523, 4626-4632.

33. Bao, S.D. Soil agrochemical analysis, 3rd ed.; China agriculture press: Beijing, China, 2000; pp. 145-196.

34. Lu, H.F.; Yuan, Y.G.; Campbell, D.E.; Qin, P.; Cui, L.J. Integrated water quality, emergy and economic evaluation of three bioremediation treatment systems for eutrophic water. Ecol. Eng. 2014, 69, $244-254$. [CrossRef] 
35. Li, H.; Brown, M. Emergy-based environmental accounting toward a sustainable Mongolia. J. Geogr. Sci. 2017, 27, 1227-1248. [CrossRef]

36. Wang, L.; Li, L.; Cheng, K.; Ji, C.Y.; Yue, Q.; Bian, R.J.; Pan, G.X. An assessment of emergy, energy, cost-benefits of grain production over 6 years following a biochar amendment in a rice paddy from China. Environ. Sci. Pollut. Res. 2018, 25, 9683-9696. [CrossRef] [PubMed]

37. Zhai, X.J.; Huang, D.; Tang, S.M.; Li, S.Y.; Guo, J.X.; Yang, Y.J.; Liu, H.F.; Li, J.S.; Wang, K. The emergy of metabolism in different ecosystems under the sameenvironmental conditions in the agro-pastoral ecotone of northern China. Ecol. Indic. 2017, 74, 198-204. [CrossRef]

38. Zgurovsky, M. The scenario analysis approach as a tool for decision-makers. In International Conference on Politics and Information Systems: Technologies and Applications; Vol 1: INFORMATICS AND SOCIETY, 2004; pp. 339-344.

39. Bray, S.G.; Golden, R. Scenario analysis of alternative vegetation management options on the greenhouse gas budget of two grazing businesses in north-eastern Australia. Rangeland J. 2009, 31, 137-142. [CrossRef]

40. Zhang, X.H.; Zhang, R.; Wu, J.; Zhang, Y.Z.; Lin, L.L.; Deng, S.H.; Li, L.; Yang, G.; Yu, X.Y.; Qi, H.; et al. An emergy evaluation of the sustainability of Chinese crop production system during 2000-2010. Ecol. Indic. 2016, 60, 622-633. [CrossRef]

41. Zhai, X.J.; Zhao, H.; Guo, L.Z.; Finch, D.M.; Huang, D.; Liu, K.; Tang, S.M.; Yang, Y.J.; Guo, J.X.; Li, J.H.; et al. The emergy of metabolism in the same ecosystem (maize) under different environmental conditions. J. Clean Prod. 2018, 191, 233-239. [CrossRef]

42. Ghaley, B.B.; Kehli, N.; Mentler, A. Emergy synthesis of conventional fodder maize (Zea mays L.) production in Denmark. Ecol. Indic. 2018, 87, 144-151. [CrossRef]

43. Han, Q.Y.; Hu, B.Q.; Chen, Q. Energy Evaluation of Agricultural Eco-Economic System in Du' an County of Karst Region. J. Guangxi Aca. Sci. 2010, 26, 188-192. [CrossRef]

44. Li, S.; Deng, B.K.; Shao, J.X. Study on Sustainability of Eco-Economic System in Karst Region Using Emergy Methodology: A Case Study of Guizhou Province. Ecol. Econ. 2015, 31, 90-93.

45. Zhang, C.G.; Han, J.C.; Qiu, L.; Zhu, M.Q.; Cheng, J. Energy method-based evaluation of the sustainability of the "Five-in-One" ecological orchard system. J. Agro-Environment. Sci. 2018, 37, 276-285.

46. Sun, L.; Han, J.; Wu, F.Q. Emergy and benefit evaluation of pig-methane-pomegranate recycling agriculture in Guanzhong Plain. Agric Res Arid Areas. 2015, 35, 199.

47. Anna, K.; Janusz, P.; Stefan, W.; Wzorek, M.; Królczyk, G.; Król, A. Energy and emergy analysis of mixed crop-livestock farming. E3S Web of Conferences 2017, 19, 02033. [CrossRef]

48. Wu, X.H.; Wu, F.Q.; Wu, J.; Sun, L. Emergy-based sustainability assessment for a five-in-one integrated production system of apple, grass, pig, biogas, rainwater on the loess plateau, northwest china. J. Sustain. Agric. 2015, 39, 666-690. [CrossRef]

49. Jianyuan, W. Emergy analysis of agroecosystems in shandong province of china. Chin. J. Ecol. 2007, 26, 718-722.

50. Chen, W.; Zhong, S.Z.; Geng, Y.; Chen, Y.H.; Cui, X.W.; Wu, Q.; Pan, H.Y.; Wu, R.; Tian, X. Emergy based sustainability evaluation for Yunnan Province, China. J. Clean Prod. 2017, 162, 1388-1397. [CrossRef]

51. Wang, X.L.; Tan, K.M.; Chen, Y.C.; Chen, Y.; Shen, X.F.; Zhang, L.; Dong, C.X. Emergy-based analysis of grain production and trade in China during 2000-2015. J. Clean Prod. 2018, 193, 59-71. [CrossRef]

52. Duan, N.; Lin, C.; Liu, X.D.; Wen, S.; Zhang, X. Energy analysis of biogas-linked eco-village circulating system. Trans Chin Soc Agric Eng. 2015, 31, 261-268.

53. Zhang, C.G.; Qiu, L. Comprehensive sustainability assessment of a biogas-linked agro-ecosystem: A case study in China. Clean Technol. Environ. Policy. 2018, 20, 1847-1860. [CrossRef]

54. Shrestha, B.; Chang, S.; Bork, E.; Carlyle, C. Enrichment Planting and Soil Amendments Enhance Carbon Sequestration and Reduce Greenhouse Gas Emissions in Agroforestry Systems: A Review. Forests 2018, 9 , 369. [CrossRef]

55. Castellini, C.; Bastianoni, S.; Granai, C.; Bosco, A.D.; Brunetti, M. Sustainability of poultry production using the emergy approach: comparison of conventional and organic rearing systems. Agric. Ecosyst. Environ, 2006, 114, 343-350. [CrossRef]

56. Ciotola, R.J.; Lansing, S.; Martin, J.F. Emergy analysis of biogas production and electricity generation from small-scale agricultural digesters. Ecol. Eng. 2011, 37, 1681-1691. [CrossRef] 
57. Yang, J.; Chen, B. Emergy analysis of a biogas-linked agricultural system in rural China-A case study in Gongcheng Yao Autonomous County. Appl. Energy. 2014, 118, 173-182. [CrossRef]

58. Yu, X.; Geng, Y.; Dong, H.; Fujita, T.; Liu, Z. Emergy-based sustainability assessment on natural resource utilization in 30 chinese provinces. J. Clean Prod. 2016, 133, 18-27. [CrossRef]

59. Agostinho, F.; Diniz, G.; Raúl, S.; Ortega, E. The use of emergy assessment and the geographical information system in the diagnosis of small family farms in brazil. Ecol. Model. 2008, 210, 37-57. [CrossRef]

60. Chen, G.Q.; Jiang, M.M.; Chen, B.; Yang, Z.F.; Lin, C. Emergy analysis of chinese agriculture. Agric. Ecosyst. Environ. 2006, 115, 161-173. [CrossRef]

61. Campbell, E.T.; Tilley, D.R. Relationships between renewable emergy storage or flow and biodiversity: A modeling investigation. Ecol. Model. 2016, 340, 134-148. [CrossRef]

62. Zhang, Y.; Yang, Z.; Yu, X. Ecological network and emergy analysis of urban metabolic systems: Model development, a case study of four chinese cities. Ecol. Model., 2009, 220, 1431-1442. [CrossRef]

63. Martin, J.F.; Diemont, S.A.W.; Powell, E.; Stanton, M.; Levy-Tacher, S. Emergy evaluation of the performance and sustainability of three agricultural systems with different scales and management. Agric. Ecosyst. Environ. 2006, 115, 128-140. [CrossRef]

64. Cho, C.J. An exploration of reliable methods of estimating emergy requirements at the regional scale: Traditional emergy analysis, regional thermodynamic input-output analysis the conservation rule-implicit method. Ecol. Model. 2013, 251, 288-296. [CrossRef]

65. Patterson, M.G. Are all processes equally efficient from an emergy perspective? Analysis of ecological and economic networks using matrix algebra methods. Ecol. Model. 2012, 226, 77-91. [CrossRef]

66. Lu, H.F.; Campbell, D.E.; Li, Z.A.; Ren, H. Emergy synthesis of an agro-forest restoration system in lower subtropical China. Ecol. Eng. 2006, 27, 175-192. [CrossRef]

67. Lan, S.F.; Odum, H.T.; Liu, X.M. Energy flow and emergy analysis of the agroecosystems of China. Ecol. Sci. 1998, 1, 17.

(C) 2019 by the authors. Licensee MDPI, Basel, Switzerland. This article is an open access article distributed under the terms and conditions of the Creative Commons Attribution (CC BY) license (http:// creativecommons.org/licenses/by/4.0/). 